\title{
The potential Therapeutic Effect of Adipose Tissue-derived Mesenchymal Stem Cell Transplantation on Cuprizone Model of Multiple Sclerosis in the Mice
}

\author{
Original \\ Mona A. Barkat ${ }^{1}$ Amany El-Agawany', Ayman Ahmed Khanfour', \\ Article \\ Melad N. Kelada', Iman Nabil ${ }^{2}$, Doaa Ali Abdelmonsif ${ }^{3}$, Abeer E. Dief ${ }^{4}$ \\ ${ }^{1}$ Human Anatomy and Embryology Department, ${ }^{2}$ Histology and Cell Biology Department, \\ ${ }^{3}$ Medical Biochemistry Department, ${ }^{4}$ Medical Physiology Department, Faculty of Medicine, \\ University of Alexandria.
}

\begin{abstract}
Background: Multiple Sclerosis (MS) is an autoimmune neurodegenerative disease. Current treatments have limited effect on the upstream pathophysiology of the disease. Nowadays, mesenchymal stem cells are considered to be a potential therapeutic tool for various neurodegenerative diseases. Their immune privileged status, trophic nature, and capacity to differentiate into various lineages makes them an ideal vehicle for treatment options.

Aim of the Study: the goal of this study was to assess the remyelinating potential of adipose mesenchymal stem cells (ADMSCs) in cuprizone model of MS.

Material and Methods: AD-MSCs were obtained from male mice and characterized by flow cytometry. Thirty-six female C57BL/6 mice were divided equally among three groups. Group I (control group): mice were fed with a normal diet through the entire duration of the experiment. Groups II and III: mice were fed with a $0.2 \%$ cuprizone containing diet for six weeks. By the end of the sixth week, group II and III mice received a single intravenous injection of $500 \mu$ of a complete culture medium and $1 \times 106 \mathrm{AD}$-MSCs suspended in $500 \mu \mathrm{l}$ of a complete culture medium respectively. Neurological tests were done before and 9-10 days after the injection. All mice were euthanized at day 10 and corpus callosum was processed for further histological and biochemical examination. Morphometric study was done to assess remyelination. Migration of the male AD-MSCs into the female mice brain was confirmed by SRY gene expression. The obtained data were further statistically analyzed.

Results: Cuprizone intake for 6 weeks caused extensive demyelination similar to MS accompanied by neurological deficits and change in the oxidative stress. Intravenous administration of AD-MSCs in group III enhanced the remyelination process improved the motor and cognitive functions and decrease the oxidant level.

Conclusion: AD-MSCs provide a valuable potential treatment for neurodegenerative demyelinating diseases such as MS.
\end{abstract}

Received: 16 June 2019, Accepted: 04 August 2019

Key Words: Behavior test, cuprizone, multiple sclerosis, stem cell.

Corresponding Author: Mona Abdelfatah Barkat, BSc, Human Anatomy and Embryology Department, Faculty of Medicine, Alexandria University, Alexandria, Egypt, Tel.: +20 1283134821, E-mail: monabarakat141@gmail.com

ISSN: $1110-0559$, Vol. 43, No. 1

\section{INTRODUCTION}

Multiple sclerosis (MS) is the most common demyelinating disease affecting the central nervous system (CNS). It is considered the most common neurological disorder in young adults specifically in females ${ }^{[1]}$. Four clinical forms of multiple sclerosis are defined: relapsingremitting, secondary progressive, primary progressive, and progressive-relapsing $\mathrm{MS}^{[2]}$. Common manifestations of MS are sensory impairment, motor and cognitive deficits which seriously impact the patients with disabilities ${ }^{[3]}$.

Inflammation of the central nervous system is considered the cause of damage in MS. Unfortunately, the triggers of this inflammation are still unknown. However, several studies have suggested that development of MS is influenced by genetic, environmental, and infectious agents ${ }^{[4]}$. To date, no curative treatment exists for patients with MS. Disease-modifying therapies are used nowadays only to reduce the progression of the disease and ameliorate the patient lifestyle ${ }^{[5]}$.

Stem cells are immature cells, able to self-renew and differentiate into multiple cell types derived from either ectoderm, endoderm or mesoderm according to their potency. Stem cells have four sources to be obtained; from embryonic tissue, fetal tissues, specific locations in the adult organism and genetically reprogrammed somatic cells ${ }^{[6]}$.

Mesenchymal stem cells (MSCs) are non-hematopoietic stromal cells that can differentiate into cells derived from 
mesoderm including osteoblasts, chondrocytes, and adipocytes. Furthermore, MSCs can cross their lineage and differentiate into other cell types such as hepatocytes, keratinocytes, and neurons ${ }^{[7]}$. MSCs could be isolated from a plethora of tissues. Nowadays, much focus has been gained on adipose tissue as an accessible and a rich source of MSCs. Comparatively, adipose-derived mesenchymal stem cells (AD-MSCs) possess more superior characteristics than bone marrow-derived mesenchymal stem cells (BMMSCs) and considered recently by researchers as the ultimate source to harvest the adult stem cells ${ }^{[8]}$.

Thus, the current study was conducted to evaluate the potential therapeutic role of AD-MSCs in enhancing the myelination process of the demyelinated white matter of the central nervous system in a cuprizone-induced experimental model of multiple sclerosis.

\section{MATERIALS AND METHODS}

Animals:36 female black mice (C57BL/6) 6-8 weeks old, were obtained from the animal house of Anatomy Department, Faculty of Medicine, Alexandria University. Mice were allowed to acclimate for 2 weeks under standard temperature and humidity laboratory conditions and normal light/dark cycle. All experimental trials were conducted according to the Guide for Care and Use of Laboratory Animals and were accepted by the Medical Ethics Committee of Faculty of Medicine, Alexandria University.

\section{Induction of demyelination by cuprizone}

Demyelination was induced by feeding mice daily with cuprizone (Sigma-Aldrich, Germany, CAS Number 370-81-0) mixed with standard chow in a concentration of $0.2 \%(0.2 \mathrm{~g}$ of cuprizone was added to each $100 \mathrm{~g}$ of chow). The feed was changed three times per week for 6 weeks $^{[9]}$.

Experimental design: 36 female mice were randomly divided equally among three groups $(n=12)$.

Group I (control group): The animals were fed with a cuprizone-free normal diet.

Group II (demyelination group): The animals were fed daily with the cuprizone as described before. By the end of the sixth week and cessation of cuprizone intake (day 0), they received a single intravenous injection of 500 $\mu 1$ of a complete culture medium (CCM) into the tail vein (day 1$)^{[10]}$.

Group III (transplanted group): The animals were fed daily with the cuprizone-containing diet for 6 weeks as in group II followed by a single intravenous injection of about $1 \times 106$ AD-MSCs suspended in $500 \mu 1$ of a CCM into the tail vein (day 1$)^{[10]}$.

During the whole experimental period, the weight of the mice was weekly measured and recorded.

\section{Isolation and culture of Adipose tissue-derived mesenchymal stem cells (AD-MSCs): ${ }^{[1]}$}

Male mice were used for stem cell isolation in which the animals were sacrificed under anesthesia, the adipose tissue was collected from abdominal, inguinal and perinephric pad of fat under biosafety cabinet into a falcon tube containing phosphate buffered-saline (PBS) supplemented with $3 \%$ penicillin/streptomycin and $1 \%$ amphotericin, followed by mincing the collected tissues in a sterile tissue culture plate.

The sample was digested with $0.075 \%$ collagenase type I (Nordmark Arzneimittel GmbH and Co. KG, Lot N 18201) for $30 \mathrm{~min}$ at $37^{\circ} \mathrm{C}$. The infranatant, the pelleted stromal vascular fraction (SVF), was aspirated using serological pipette into a falcon tube, centrifuged at 1400 rpm for $5 \mathrm{~min}$ then the supernatant was aspirated.

The resultant pellet was suspended in $5 \mathrm{ml}$ of PBS and filtered through $100 \mu \mathrm{m}$ cell strainer. The sample was recentrifuged, the supernatant was discarded, and the obtained pellet was cultured in $25 \mathrm{~cm}^{2}$ tissue culture flask containing Dulbecco's modified Eagle's medium (DMEM, Sigma-Aldrich, St. Louis, United States) supplemented with $10 \%$ fetal bovine serum (FBS, Sigma-Aldrich, St. Louis, United States), 1\% L-glutamine (Lonza Inc, USA), $1 \%$ pen/ strept (Lonza Inc, USA) then incubated in a 5\% $\mathrm{CO} 2$ humidified incubator at $37^{\circ} \mathrm{C}$.

Daily examination of the cultured cells was done using a phase contrast inverted microscope (Olympus Bx41) equipped with a digital camera. The medium was renewed every three days in order to remove non-adherent cells until the confluence reached about $80-90 \%$ at day 10 (primary culture) then subsequent subcultures were done up to passage 3 (p 3 ).

\section{Characterization of AD-MSCs by flow cytometry: ${ }^{[12]}$}

At the third passage ( $\mathrm{p} 3$ ), the cells were detached with $0.25 \%$ trypsin-EDTA solution, washed with PBS, and incubated with monoclonal antibodies for CD90 (Abcam, UK), which is one of the MSCs surface markers, in addition to CD34(Abcam, UK); a hemopoietic surface marker, at room temperature for $30 \mathrm{~min}$ in the dark.

The cells were subsequently washed three times with PBS and resuspended in $500 \mu \mathrm{L}$ fluorescent activated cell sorting (FACS) buffer. 15x103 gated events were analyzed using a FACS Calibur flow cytometer (Becton Dickinson, San Diego, Calif, USA) running Cell Quest TM Pro software (Becton Dickinson, USA).

Neurological and behavioral Tests: They were conducted for all the mice in the study at end of the sixth week and repeated 8-10 days later on (before the termination of the whole experiment.

A. Rotarod test: It was used to test motor co-ordination 
and motor learning skills. The device consists of a rotating drum accelerating from 4 to 20 turns per min. For 2 days, mice were trained on the rotarod three trials per day. Each mouse was positioned independently on the drum and the latency of falling down was recorded at a speed of twenty revolutions per min. Each mouse underwent three trials and the average score was taken ${ }^{[9]}$.

B. Open-field assessment: This test was used to assess the activity and the exploratory response. The open field is a black arena, $50 \times 30 \times 18 \mathrm{~cm}$, divided into $10 \times 10 \mathrm{~cm}$ squares. Two areas were distinguished in the open field; an area $15 \mathrm{~cm}$ from the wall comprising the periphery and the rest of the open field comprising the center. At the start, the mouse was positioned in the corner opposite the wall. Afterwards, the mouse was permitted to explore the surroundings for three min. The number of the crossed squares and the rearing numbers were counted manually ${ }^{[13]}$.

C. Passive avoidance test: To evaluate the long-term memory, Step-Through Passive Avoidance Task was used. The used apparatus is divided by a sliding barrier into light $\left(10 \_12 \_15 \mathrm{~cm}^{3}\right)$ and dark chambers $\left(14 \_18 \_15 \mathrm{~cm}^{3}\right)$. Individully, each mouse was positioned within the light chamber for $30 \mathrm{~s}$, then the sliding barrier was lifted, permitting the mouse to enter the dark chamber (retention time 1).

When the mouse moved into the darkness, the barrier was slid down and an electrical foot shock $(0.3 \mathrm{~mA}$, $50 \mathrm{~Hz}, 5 \mathrm{~s}$ ) was received. By the next day, the mouse was positioned in the light chamber for $30 \mathrm{~s}$, and the sliding barrier was then raised. The delay to go into the dark chamber for up to $120 \mathrm{~s}$ (retention time 2) was recorded ${ }^{[14]}$.

Histological study: At day 10 after cessation of cuprizone, mice were decapitated under anesthesia, and the brain tissues were immediately excised and dissected into two hemispheres. All the right hemispheres were fixed in 3\% phosphate buffered- glutaraldehyde $(\mathrm{pH} 7.4)$ for $24 \mathrm{~h}$ at $4{ }^{\circ} \mathrm{C}$ for further histological processing ${ }^{[15]}$, while the left hemispheres were stored at $-80^{\circ} \mathrm{C}$ for biochemical and molecular analyses.

The right hemispheres were dissected out carefully, blocks of approximately $1 \mathrm{~mm}^{3}$ were cut from the body of the corpus callosum at the level of the anterior commissure and processed to get semithin sections for light microscopic examination and ultrathin sections for transmission electron microscopy (TEM).

1. Light microscopy: Semithin sections $(0.5 \mathrm{~mm}$ thick), were obtained from blocks processed for the electron microscopy and stained with Toluidine blue stain for light microscopic examination ${ }^{[16]}$. Further processing was done for TEM study.

2. Transmission electron microscopy: The specimens were further post-fixed in $1 \%$ osmium tetroxide in phosphate buffer for 1-2 hours and embedded in epoxy resin. Ultrathin sections of $80 \mathrm{~nm}$ thick were obtained and stained with uranyl acetate for $20 \mathrm{~min}$, followed by lead citrate for $10 \mathrm{~min}^{[17]}$.
Electron micrographs were obtained by TEM (Jeol 100 CX, Tokyo, Japan) equipped with a digital camera at the electron microscopy unit, Faculty of Science, Alexandria University.

Morphometric analysis: Electron micrographs were obtained and the percentage of the myelinated fibers, axon diameter, fiber diameter, myelin thickness, G- ratio and the size of mitochondria were analyzed morphometrically in seven photos for each group, using the image processing and analysis software (Image J, version 1.52e).

The number of myelinated and demyelinated fibers was counted manually in each group. Myelinated fiber profiles inside the counting frame or partly inside the counting frame but only touching the counting lines were included for counting.

In a cross-section, the axon diameter was automatically measured using edge detection software from which the diameter of a circle of an equivalent area was calculated. On the other hand, the fiber diameter, in a transverse section was measured manually and again, the diameter of a circle of an equivalent area was calculated. The minimum measurement of the diameter was used. Myelin sheath thickness was calculated by subtracting the minimum axon diameter from the minimum fiber diameter and dividing by two. The G- ratio; the ratio of the inner axonal diameter to the total outer diameter, was considered as a functional and structural index of optimal axonal myelination ${ }^{[18,19]}$.

Measurement of oxidative stress: A part of the corpus callosum was homogenized in 10 times $(\mathrm{w} / \mathrm{v})$ ice-cold $0.1 \mathrm{M}$ phosphate buffer ( $\mathrm{pH} 7.4$ ) and centrifuged at $10,000 \mathrm{~g}$ for 15 min at $4{ }^{\circ} \mathrm{C}$ for retrieval of the supernatant. The antioxidant defense marker; superoxide dismutase (SOD) and the lipid peroxidation marker; malondialdehyde (MDA) levels in the supernatant were assayed spectrophotometrically according to the instructions of Bio diagnostic kits (Bio diagnostic, Giza, Egypt). Results were expressed in U/g tissue (SOD activity) and nmol/g tissue (MDA) ${ }^{[20,21]}$.

Quantitative reverse transcription- polymerase chain reaction (RT-qPCR) for detection of sexdetermining region $Y$ (SRY) mRNA expression: To evaluate the migration and homing of AD-MSCs from the peripheral circulation into the CNS, we used the corpus callosum of left hemispheres to perform quantitative reverse transcription-polymerase chain reaction for detection of sex-determining region Y (SRY) mRNA expression.

Total RNA extraction: Total RNA, including mRNA, was extracted from the samples using Gene JET RNA Purification Kit following the manufacturer's protocol (Thermo Fisher Scientific, Inc., Waltham, MA, USA). The isolated RNA was suspended in RNAse-free DEPC (Diethyl-pyro-carbonate)-treated water and stored at $-80^{\circ} \mathrm{C}$ until further processing ${ }^{[22]}$.

Quantitative RT-PCR-based detection of SRY expression: $100 \mathrm{ng}$ of total RNA were used for reverse transcription in a $20 \mu \mathrm{l}$ reaction volume according to the 
manufacturer's protocol of High Capacity cDNA Reverse Transcription Kit (Invitrogen, NY, USA). Next, real-time PCR reaction was performed in Step One real-time PCR system (Applied Biosystems, USA). The synthesized cDNA was amplified in duplicates using 2X Maxima SYBR Green qPCR Master Mix (Applied Biosystems, USA) ${ }^{[23]}$.

The specific primer pair for SRY was the sense primer AGCTCTTACACTTTAAGTTTTGAC and the antisense primer GCAGCTCTACTCCAGTCTTGCC (GenBank accession number NM_011564.1).

The amplification cycle included one cycle at $95^{\circ} \mathrm{C}$ for $10 \mathrm{~min}$ followed by 40 cycles of denaturation at $95^{\circ} \mathrm{C}$ for $15 \mathrm{sec}$, a $65^{\circ} \mathrm{C}$ annealing step for $30 \mathrm{sec}$, and an extension step at $72^{\circ} \mathrm{C}$ for $30 \mathrm{sec}$. A melting curve analysis was done to confirm the identity of the PCR product. In addition, a negative control was included with each PCR run to confirm the specificity of the reaction.

The comparative CT method for gene expression was used for data analysis using Step One ${ }^{\mathrm{TM}}$ Software v2.3. Results were normalized to the housekeeping gene glyceraldehyde-3-phosphate dehydrogenase (GAPDH) and were expressed as fold change from the control group.

Statistical analysis: Data were fed to the computer and analyzed using IBM SPSS software package version 20.0. (Armonk, NY: IBM Corp). The Kolmogorov-Smirnov test was used to verify the normality of distribution. Quantitative data were described using range (minimum and maximum), mean, standard deviation and median. Significance of the obtained results was judged at the $P \leq 0.05$.

\section{RESULTS}

\section{The weight of mice}

With cuprizone intake, there was a significant decrease in the body weight observed in the demyelination group (group II) and transplanted group (group III) during the first six weeks of the experiment, which was followed by a gradual weight gain during the next 10 days with cessation of CZ. Despite the time-dependent increase in weight, mice of the demyelination and transplanted groups weighed significantly less than control mice over the course of the last 10 days of the experiment. (Table 1, Figure 1)

\section{Characterization of the AD-MSCs}

A. Microscopic appearance of AD-MSCs: During primary culture; passage zero ( $p$ 0), ADMSCs exhibited spindle-shaped fibroblast-like morphology which gradually increased in number. Subsequent passages showed a rapid proliferation of AD-MSCs. (Figure 2)

B. Immunophenotyping of AD-MSCs by flow cytometry: The flow cytometric analysis of cellsurface markers of AD-MSCs at passage three, using antibody against AD-MSCs marker (CD90) and another one against hematopoietic antigen (CD34), showed that $85.1 \%$ of cells were positive for anti CD90, while only $0.01 \%$ of cells were positive for anti CD34 (Figure 3).

\section{Neurological and behavioral tests}

A. Rotarod test: With $\mathrm{CZ}$ diet for six weeks (groups II and III), the mice showed a significant deficit in rotarod performance where the time was taken to fall decreased significantly in comparison to the control group. After stem cell transplantation (in group III), an improvement was noticed in rotarod performance and the mice spent more time up. (Table 2, Figure 4)

B. Open field test: By the end of the sixth week of CZ intake, exploratory behavior reduced significantly in cuprizone fed mice (groups II and III) as shown by decreased number of crossed squares and number of rearing.

After AD-MSCs transplantation in group III, there was a significant improvement in the exploratory behavior as compared to group II regarding the number of squares crossed by the transplanted group $(p=0.003 *)$ and the number of rearing $\left(p=0.010^{*}\right)$ (Table 3 , Figure 5$)$.

C. Passive avoidance test: After six weeks of cuprizone, there was a significant decrease in the retention time 2 in group II $\left(p=0.001^{*}\right)$ and group III $\left(p<0.001^{*}\right)$ in comparison to the control group.

AD-MSCs transplantation resulted in significant improvement in group III in comparison to group II $(p=0.003 *)$. In group III, the mice showed prolongation in retention time 2 , almost similar to the control group which denoted improving the long-term memory $(p=0.327)$. (Table 4, Figure 6)

\section{Light microscopic examination of corpus callosum sections (Toluidine blue stain)}

Histological examination of the control group (group I) revealed predominantly myelinated nerve fibers arranged in groups with the glial cells aligned in rows in between the nerve fasciculi. (Figure 7) The nerve fibers of demyelination group (group II) appeared mostly demyelinated (Figure 8a), with large astrocytes among them (Figure 8b), while the transplanted group (group III) showed numerous remyelinating nerve fibers with glial cells (Figure 9).

\section{Electron microscopic examination}

\section{Control group (group I)}

Ultrastructural examination of a section of the control group corpus callosum revealed predominantly myelinated nerve fibers, (Figure 10a) each consisted of an axon covered with multiple lamellated layers of myelin sheath, (Figure 10b). The oligodendroglia were seen arranged in rows between the myelinated nerves, (Figure 11a). These 
cells were identified by their relatively dense cytoplasm and large dark nuclei. The cytoplasm contained Golgi apparatus, many mitochondria, short cisternae of rough endoplasmic reticulum and dark inclusions, (Figure 11b). On the other hand, the astrocytes were distinguished by their large size, irregular shape, pale cytoplasm and pale nucleus with a thin rim of peripheral heterochromatin. Many ribosomes, mitochondria, rough endoplasmic reticulum, and cytoplasmic inclusions were further encountered, (Figure 12).

\section{Demyelination group (group II)}

Microscopic examination of this group showed that the section of the corpus callosum exhibited thoroughly demyelinated appearance with few myelinated nerve fibers were still depicted. Enlarged mitochondria were seen inside the axoplasm, (Figure 13). Some glial cells revealed very small size with elongated heterochromatic nuclei and dense cytoplasm, (Figure 14a). Large astrocytes with long processes were depicted as well, (Figure 14b).

\section{Transplanted group (group III)}

This group revealed numerous remyelinating nerve fibers inside a section of the corpus callosum, yet, few unmyelinated nerve fibers were also encountered, (Figure 15). Normally appearing oligodendroglia and large astrocytes were depicted as well, (Figures $16 \mathrm{a}$ and $\mathrm{b}$ ).

\section{Morphometric results}

i. The number of myelinated nerve fibers: The mean number of myelinated fibers in the transplanted group was significantly higher than the demyelination group $\left(p=0.035^{*}\right)$ but was still significantly lowered as compared to the control group $\left(p=0.035^{*}\right)$ (Table 5, Figure 17)

ii. G-ratio: The mean axon diameter and fiber diameter of control group were significantly larger than both the demyelination group and the transplanted group. However, in the transplanted group, the fiber diameter was significantly larger than the demyelination group. On the other hand, the myelin thickness in the transplanted group was significantly larger than that of the demyelination group. Thus, the G-ratio of the transplanted group did not show any significant difference from the control group, while in the demyelination group it was statistically the highest. (Table 6, Figures 18A, B, C, D).

iii. Mitochondrial size: The size of the mitochondria in the demyelination group was significantly larger than both control group and transplanted group. while a non-significant difference was depicted between the control and the transplanted groups. (Table 6, Figure 19).

Quantitative reverse transcription-polymerase chain reaction for detection of SRY mRNA, Y chromosome specific sequence:

Gene expression quantified by Real time-qPCR results showed that SRY mRNA expression was identified in the corpus callosum of the female mice in group III after ten days of intravenous injection of AD-MSCs obtained from the male mice. (Table 7, Figure 20).

\section{Oxidative stress level}

In demyelination group, there was a significant decrease in the level of SOD than the other two groups $(p<0.05)$, while the transplanted group showed significantly increased level as compared to group II $(p=0.01)$. On the other hand, the MDA level was significantly higher in demyelination group than the control group $(p=0.030)$. The level decreased by AD- MSCs transplantation in group III, yet, it was statistically insignificant from the other two groups. (Table 8, Figure 21) 
Table 1: The mice body weight (in grams) for the three different groups within the first six weeks and the following ten days of the experiment

\begin{tabular}{|c|c|c|c|c|c|c|c|c|}
\hline & $1^{\text {st }}$ week & $2^{\text {nd }}$ week & $3^{\text {rd }}$ week & $4^{\text {th }}$ week & $5^{\text {th }}$ week & $6^{\text {th }}$ week & $5^{\text {th }}$ day later on & $10^{\text {th }}$ day \\
\hline \multicolumn{9}{|l|}{ Group I } \\
\hline Min. - Max. & $25.0-25.0$ & $24.0-25.0$ & $23.0-27.0$ & $23.0-28.0$ & $24.0-29.0$ & $26.0-30.0$ & $27.0-32.0$ & $29.0-33.0$ \\
\hline Mean $\pm \mathrm{SD}$ & $25.0 \pm 0.0$ & $24.67 \pm 0.50$ & $25.78 \pm 1.20$ & $26.11 \pm 1.45$ & $27.0 \pm 1.41$ & $28.22 \pm 1.30$ & $29.89 \pm 1.62$ & $31.44 \pm 1.24$ \\
\hline Median & 25.0 & 25.0 & 26.0 & 26.0 & 27.0 & 28.0 & 30.0 & 32.0 \\
\hline $\mathrm{p}^{0}$ & & 1.000 & 1.000 & 1.000 & 0.079 & $0.002 *$ & $<0.001 *$ & $<0.001 *$ \\
\hline \multicolumn{9}{|l|}{ Group II } \\
\hline Min. - Max. & $25.0-25.0$ & $22.0-24.0$ & $21.0-23.0$ & $20.0-22.0$ & $20.0-22.0$ & $20.0-22.0$ & $21.0-23.0$ & $21.0-24.0$ \\
\hline Mean \pm SD & $25.0 \pm 0.0$ & $23.20 \pm 0.84$ & $22.20 \pm 0.84$ & $21.20 \pm 0.84$ & $21.40 \pm 0.89$ & $20.80 \pm 0.84$ & $21.80 \pm 0.84$ & $22.60 \pm 1.14$ \\
\hline Median & 25.0 & 23.0 & 22.0 & 21.0 & 22.0 & 21.0 & 22.0 & 23.0 \\
\hline $\mathrm{p}^{0}$ & & 0.240 & $0.048^{*}$ & $0.015^{*}$ & $0.024 *$ & $0.010^{*}$ & $0.029 *$ & 0.259 \\
\hline \multicolumn{9}{|l|}{ Group III } \\
\hline Min. - Max. & $25.0-25.0$ & $22.0-24.0$ & $20.0-22.0$ & $16.0-20.0$ & $16.0-20.0$ & $14.0-18.0$ & $18.0-21.0$ & $20.0-22.0$ \\
\hline Mean $\pm \mathrm{SD}$ & $25.0 \pm 0.0$ & $22.86 \pm 0.69$ & $20.86 \pm 0.69$ & $19.14 \pm 1.46$ & $18.86 \pm 1.46$ & $17.14 \pm 1.46$ & $19.86 \pm 1.35$ & $20.86 \pm 0.69$ \\
\hline Median & 25.0 & 23.0 & 21.0 & 20.0 & 19.0 & 18.0 & 20.0 & 21.0 \\
\hline$p^{0}$ & & $0.005^{*}$ & $<0.001^{*}$ & $0.001 *$ & $0.001 *$ & $<0.001 *$ & $0.002 *$ & $<0.001 *$ \\
\hline$F$ & - & $17.194 *$ & $53.894 *$ & $56.525^{*}$ & $77.738^{*}$ & $156.691 *$ & $116.820^{*}$ & $225.876^{*}$ \\
\hline$P$ & - & $<0.001 *$ & $<0.001 *$ & $<0.001 *$ & $<0.001 *$ & $<0.001 *$ & $<0.001 *$ & $<0.001 *$ \\
\hline$p^{l}$ & - & $0.002 *$ & $<0.001 *$ & $<0.001^{*}$ & $<0.001 *$ & $<0.001 *$ & $<0.001 *$ & $<0.001 *$ \\
\hline$p^{2}$ & - & $<0.001 *$ & $<0.001 *$ & $<0.001^{*}$ & $<0.001 *$ & $<0.001 *$ & $<0.001^{*}$ & $<0.001^{*}$ \\
\hline$p^{3}$ & - & 0.649 & 0.075 & $0.044^{*}$ & $0.012 *$ & $<0.001 *$ & 0.068 & $0.030 *$ \\
\hline
\end{tabular}

p0: $p$ value for Post Hoc test (Bonferroni) for ANOVA with repeated measures for comparing between $1^{\text {st }}$ period and each other

F: F test (ANOVA) with repeated measures, Sig. bet. periods were done using Post Hoc Test (Tukey)

$\mathrm{p}: p$ value for comparing between the three groups

$\mathrm{p} 1: p$ value for comparing between group I and group II.

p2: $p$ value for comparing between group I and group III.

p3: $p$ value for comparing between group II and group III.

*: Statistically significant at $p \leq 0.05$

Table 2: Table for the time on Rotarod test (sec.) showing the time that was spent before falling in the different experimental groups at the end of sixth week and ten days later on

\begin{tabular}{|c|c|c|c|c|c|c|}
\hline & \multicolumn{2}{|c|}{ Group I } & \multicolumn{2}{|c|}{ Group II } & \multicolumn{2}{|c|}{ Group III } \\
\hline & At the $6^{\text {th }}$ week & At $10^{\text {th }}$ day & At the $6^{\text {th }}$ week & At $10^{\text {th }}$ day & At the $6^{\text {th }}$ week & At $10^{\text {th }}$ day \\
\hline \multicolumn{7}{|l|}{ Rotrod } \\
\hline Min. - Max. & $60.0-60.0$ & $59.0-60.00$ & $7.0-16.0$ & $10.0-22.0$ & $6.0-60.0$ & $20.0-60.0$ \\
\hline Mean \pm SD & $60.0 \pm 0.0$ & $59.83 \pm 0.39$ & $10.67 \pm 2.81$ & $16.17 \pm 3.61$ & $20.0 \pm 15.36$ & $33.0 \pm 11.24$ \\
\hline Median & 60.0 & 60.0 & 9.50 & 16.0 & 19.50 & 31.0 \\
\hline $\mathrm{p}^{1}$ & & & $<0.001^{*}$ & $<0.001^{*}$ & $0.002^{*}$ & $0.017^{*}$ \\
\hline $\mathrm{p}^{2}$ & & & & & 0.123 & $0.007^{*}$ \\
\hline${ }^{\mathrm{z}} \mathrm{p}^{3}$ & \multicolumn{2}{|c|}{0.157} & \multicolumn{2}{|c|}{$0.002^{*}$} & \multicolumn{2}{|c|}{$0.012^{*}$} \\
\hline$\% \mathrm{Ch}$. & \multicolumn{2}{|c|}{-0.28} & \multicolumn{2}{|c|}{55.0} & \multicolumn{2}{|c|}{120.6} \\
\hline
\end{tabular}

p1: $p$ value for Post Hoc Test (Dunn's for multiple comparisons test) comparing between group I and each other groups

p2: $p$ value for Post Hoc Test (Dunn's for multiple comparisons test) comparing between group II and Group III

zp3: $p$ value for Wilcoxon signed ranks test for comparing between before and after in each group

*: Statistically significant at $p \leq 0.05$ 
Table 3: Table representing Open field test regarding the number of the crossed squares and the number of rearing in the three different groups at the end of sixth week and ten days later on

\begin{tabular}{|c|c|c|c|c|c|c|}
\hline & \multicolumn{2}{|c|}{ Group I } & \multicolumn{2}{|c|}{ Group II } & \multicolumn{2}{|c|}{ Group III } \\
\hline & At the $6^{\text {th }}$ week & At $10^{\text {th }}$ day & At the $6^{\text {th }}$ week & At $10^{\text {th }}$ day & At the $6^{\text {th }}$ week & At $10^{\text {th }}$ day \\
\hline \multicolumn{7}{|c|}{ Number of crossed squares } \\
\hline Min. - Max. & $93.0-161.0$ & $95.0-160.0$ & $13.0-48.0$ & $63.0-100.0$ & $15.0-50.0$ & $80.0-160.0$ \\
\hline Mean \pm SD & $132.17 \pm 21.8$ & $131.75 \pm 21.9$ & $31.42 \pm 14.53$ & $78.75 \pm 10.91$ & $29.90 \pm 10.97$ & $112.8 \pm 26.07$ \\
\hline Median & 127.5 & 128.0 & 40.0 & 79.50 & 31.0 & 110.0 \\
\hline $\mathrm{p}^{1}$ & & & $<0.001^{*}$ & $<0.001^{*}$ & $<0.001^{*}$ & 0.208 \\
\hline $\mathrm{p}^{2}$ & & & & & 0.813 & $0.003^{*}$ \\
\hline${ }^{\mathrm{z}} \mathrm{p}^{3}$ & \multicolumn{2}{|c|}{0.681} & \multicolumn{2}{|c|}{$0.002^{*}$} & \multicolumn{2}{|c|}{$0.005^{*}$} \\
\hline \multicolumn{7}{|c|}{ Number of rearing } \\
\hline Min. - Max. & $25.0-60.0$ & $23.0-64.0$ & $0.0-3.0$ & $3.0-17.0$ & $0.0-0.0$ & $12.0-35.0$ \\
\hline Mean \pm SD & $43.42 \pm 9.66$ & $42.58 \pm 11.57$ & $0.50 \pm 1.17$ & $10.67 \pm 3.75$ & $0.0 \pm 0.0$ & $22.20 \pm 7.80$ \\
\hline Median & 44.0 & 41.50 & 0.0 & 11.0 & 0.0 & 18.50 \\
\hline $\mathrm{p}^{1}$ & & & $<0.001^{*}$ & $<0.001^{*}$ & $<0.001^{*}$ & $0.020^{*}$ \\
\hline $\mathrm{p}^{2}$ & & & & & 0.630 & $0.010^{*}$ \\
\hline${ }^{\mathrm{z}} \mathrm{p}^{3}$ & \multicolumn{2}{|c|}{0.430} & \multicolumn{2}{|c|}{$0.002^{*}$} & \multicolumn{2}{|c|}{$0.005^{*}$} \\
\hline
\end{tabular}

Zp0: $p$ value for Wilcoxon signed ranks test for comparing between before and after in each group

$\mathrm{p} 1: p$ value for comparing between group I and each other groups

$\mathrm{p} 2: p$ value for comparing between group II and group III

p3: $p$ value for comparing between before and after*: Statistically significant at $p \leq 0.05$.

Table 4: Comparison between different groups in the Passive avoidance test according to retention latency time 2 (sec.) by the end of the sixth week of the experiment and ten days later on

\begin{tabular}{|c|c|c|c|c|c|c|}
\hline & \multicolumn{2}{|c|}{ Group I } & \multicolumn{2}{|c|}{ Group II } & \multicolumn{2}{|c|}{ Group III } \\
\hline & At the $6^{\text {th }}$ week & At $10^{\text {th }}$ day & At the $6^{\text {th }}$ week & At $10^{\text {th }}$ day & At the $6^{\text {th }}$ week & At $10^{\text {th }}$ day \\
\hline \multicolumn{7}{|c|}{ Passive avoidance test.(retention time 2) } \\
\hline Min. - Max. & $80.0-120.0$ & $78.0-123.0$ & $10.0-60.0$ & $15.0-90.0$ & $6.0-60.0$ & $32.0-120.0$ \\
\hline Mean $\pm \mathrm{SD}$ & $108.33 \pm 14.0$ & $109.0 \pm 13.6$ & $29.83 \pm 12.55$ & $44.58 \pm 30.03$ & $18.25 \pm 15.28$ & $92.70 \pm 33.53$ \\
\hline Median & 115.0 & 112.0 & 29.50 & 40.0 & 13.00 & 100.0 \\
\hline $\mathrm{p}^{1}$ & & & $0.001^{*}$ & $<0.001^{*}$ & $<0.001^{*}$ & 0.327 \\
\hline $\mathrm{p}^{2}$ & & & & & 0.095 & $0.003^{*}$ \\
\hline${ }^{\mathrm{z}} \mathrm{p}^{3}$ & \multicolumn{2}{|c|}{0.692} & \multicolumn{2}{|c|}{0.239} & \multicolumn{2}{|c|}{$0.005^{*}$} \\
\hline$\%$ Ch. & \multicolumn{2}{|c|}{0.64} & \multicolumn{2}{|c|}{107.7} & \multicolumn{2}{|c|}{672.9} \\
\hline
\end{tabular}

H: H for Kruskal Wallis test, Pairwise comparison bet. each 2 groups was done using Post Hoc Test (Dunn's for multiple comparisons test) $\mathrm{p}: p$ value for comparing between the three groups

$\mathrm{Zp0}$ : $p$ value for Wilcoxon signed ranks test for comparing between before and after in each group

$\mathrm{p} 1$ : $p$ value for comparing between Group I and Group II

$\mathrm{p} 2$ : $p$ value for comparing between Group I and Group III

p3: $p$ value for comparing between Group II and Group III

*: Statistically significant at $p \leq 0.05$. 
Table 5: Comparison between the three studied groups according to the mean number of the myelinated axons of the corpus callosum

\begin{tabular}{lcccc}
\hline & Group I & Group II & Group III & H \\
\hline Myelinated axons & & & & \\
Min. - Max. & $82.0-143.0$ & $0.0-8.0$ & $40.0-72.0$ & \\
Mean \pm SD. & $110.0 \pm 21.62$ & $2.43 \pm 3.10$ & $54.43 \pm 10.05$ & $17.865^{*}$ \\
Median & 103.0 & 1.0 & 53.0 & $<0.001^{*}$ \\
Sig. bet. Groups & & $p 1<0.001^{*}, p 2=0.035^{*}, p 3=0.035^{*}$ & & \\
\hline
\end{tabular}

H: $\mathrm{H}$ for Kruskal Wallis test, Pairwise comparison between each 2 groups was done using Post Hoc Test (Dunn's for multiple comparisons test) $\mathrm{p} 1: p$ value for comparing between group I and group II.

p2: $p$ value for comparing between group I and group III.

p3: $p$ value for comparing between group II and group III.

*: Statistically significant at $p \leq 0.05$.

Table 6: Comparison between the three studied groups according to axon diameter, fiber diameter, myelin thickness, G. ratio and mitochondrial size in the corpus callosum

\begin{tabular}{|c|c|c|c|c|c|}
\hline & Group I & Group II & Group III & $\mathrm{F}$ & $P$ \\
\hline \multicolumn{6}{|c|}{ Axon diameter( $(\mu \mathrm{m})$} \\
\hline Min. - Max. & $0.35-1.76$ & $0.14-0.83$ & $0.24-1.13$ & & \\
\hline Mean $\pm \mathrm{SD}$ & $0.85 \pm 0.41$ & $0.39 \pm 0.16$ & $0.56 \pm 0.19$ & $21.409^{*}$ & $<0.001^{*}$ \\
\hline Median & 0.72 & 0.37 & 0.54 & & \\
\hline Sig. bet. Groups & \multicolumn{3}{|c|}{$p 1<0.001^{*}, p 2<0.001^{*}, p 3=0.052$} & & \\
\hline \multicolumn{6}{|c|}{ Fiber diameter( $(\mu \mathrm{m})$} \\
\hline Min. - Max. & $0.66-2.37$ & $0.21-0.93$ & $0.42-1.40$ & & \\
\hline Mean \pm SD & $1.17 \pm 0.49$ & $0.46 \pm 0.16$ & $0.83 \pm 0.21$ & $37.293^{*}$ & $<0.001^{*}$ \\
\hline Median & 1.06 & 0.44 & 0.83 & & \\
\hline Sig. bet. Groups & \multicolumn{3}{|c|}{$p 1<0.001^{*}, p 2<0.001^{*}, p 3<0.001^{*}$} & & \\
\hline \multicolumn{6}{|c|}{ Myelin thickness $(\mu \mathrm{m})$} \\
\hline Min. - Max. & $0.06-0.42$ & $0.01-0.05$ & $0.08-0.23$ & & \\
\hline Mean $\pm \mathrm{SD}$ & $0.16 \pm 0.08$ & $0.04 \pm 0.01$ & $0.14 \pm 0.04$ & $51.572^{*}$ & $<0.001^{*}$ \\
\hline Median & 0.13 & 0.04 & 0.13 & & \\
\hline Sig. bet. Groups & \multicolumn{3}{|c|}{$p 1<0.001^{*}, p 2=0.128, p 3<0.001^{*}$} & & \\
\hline \multicolumn{6}{|l|}{ G. ratio } \\
\hline Min. - Max. & $0.45-0.85$ & $0.64-0.95$ & $0.49-0.81$ & & \\
\hline Mean \pm SD & $0.71 \pm 0.1$ & $0.83 \pm 0.08$ & $0.66 \pm 0.08$ & $28.219^{*}$ & $<0.001^{*}$ \\
\hline Median & 0.7 & 0.84 & 0.68 & & \\
\hline Sig. bet. Groups & \multicolumn{3}{|c|}{$p 1<0.001^{*}, p 2=0.095, p 3<0.001^{*}$} & & \\
\hline \multicolumn{6}{|c|}{ Mitochondria Size } \\
\hline Min. - Max. & $0.14-0.43$ & $0.24-0.59$ & $0.12-0.33$ & & \\
\hline Mean $\pm \mathrm{SD}$ & $0.21 \pm 0.07$ & $0.38 \pm 0.11$ & $0.20 \pm 0.05$ & $51.163^{*}$ & $<0.001^{*}$ \\
\hline Median & 0.19 & 0.37 & 0.19 & & \\
\hline Sig. bet. Groups & \multicolumn{3}{|c|}{$p 1<0.001^{*}, p 2=0.783, p 3<0.001^{*}$} & & \\
\hline
\end{tabular}

F: F for ANOVA test, Pairwise comparison between each 2 groups was done using Post Hoc Test (Tukey)

p1: $p$ value for comparing between group I and group II.

p2: $p$ value for comparing between group I and group III.

p3: $p$ value for comparing between group II and group III.

*: Statistically significant at $p \leq 0.05$ 
Table 7: Table for SRY mRNA relative expression in corpus callosum of the three experimental groups

\begin{tabular}{|c|c|c|c|c|c|}
\hline SRY mRNA fold change & Group I & Group II & Group III & $\mathrm{F}$ & $P$ \\
\hline Min. - Max. & $1.00-1.00$ & $1.00-1.00$ & $5.16-6.50$ & $197.452^{*}$ & $<0.001^{*}$ \\
\hline Mean \pm SEM. & $1.00 \pm 0.00$ & $1.00 \pm 0.00$ & $5.54 \pm 0.32$ & & \\
\hline Sig. bet. Groups & \multicolumn{5}{|c|}{$p 1=1.00, p 2<0.001^{*}, p 3<0.001^{*}$} \\
\hline
\end{tabular}

Analyzed by (one way ANOVA), followed when significant by Post Hoc Test (tukey).

$\mathrm{p} 1: p$ value for comparing between group I and group II.

p2: $p$ value for comparing between group I and group III.

p3: $p$ value for comparing between group II and group III.

*: Statistically significant at $p \leq 0.05$

Table 8: Comparison between the three studied groups according to the level of SOD and MDA in the corpus callosum

\begin{tabular}{|c|c|c|c|c|c|}
\hline & Group I & Group II & Group III & $\mathrm{F}$ & $p$ \\
\hline \multicolumn{6}{|l|}{ SOD (U/g tissue) } \\
\hline Min. - Max. & $1313.0-1575.0$ & $1100.0-1275.0$ & $1350.0-1575.0$ & & \\
\hline Mean \pm SD & $1481.5 \pm 116.43$ & $1165.75 \pm 77.30$ & $1500.0 \pm 106.07$ & $10.334^{*}$ & $0.005^{*}$ \\
\hline Median & 1519.0 & 1144.0 & 1462.5 & & \\
\hline Sig. bet. Groups & \multicolumn{3}{|c|}{$p 1=0.007^{*}, p 2=0.968, p 3=0.01^{*}$} & & \\
\hline \multicolumn{6}{|c|}{ MDA(nmol/g tissue) } \\
\hline Min. - Max. & $171.0-218.0$ & $209.0-320.0$ & $220.0-281.0$ & & \\
\hline Mean \pm SD & $188.50 \pm 20.50$ & $273.50 \pm 55.22$ & $247.50 \pm 31.14$ & $5.127^{*}$ & $0.033^{*}$ \\
\hline Median & 182.50 & 282.5 & 244.50 & & \\
\hline Sig. bet. Groups & \multicolumn{3}{|c|}{$p 1=0.030^{*}, p 2=0.131, p 3=0.621$} & & \\
\hline
\end{tabular}

F: F test (ANOVA) with repeated measures, Significance between groups were done using Post Hoc Test (Tukey)

$\mathrm{p} 1: \mathrm{p}$ value for comparing between group I and group II.

p2: $p$ value for comparing between group I and group III.

p3: $p$ value for comparing between group II and group III.

*: Statistically significant at $p \leq 0.05$

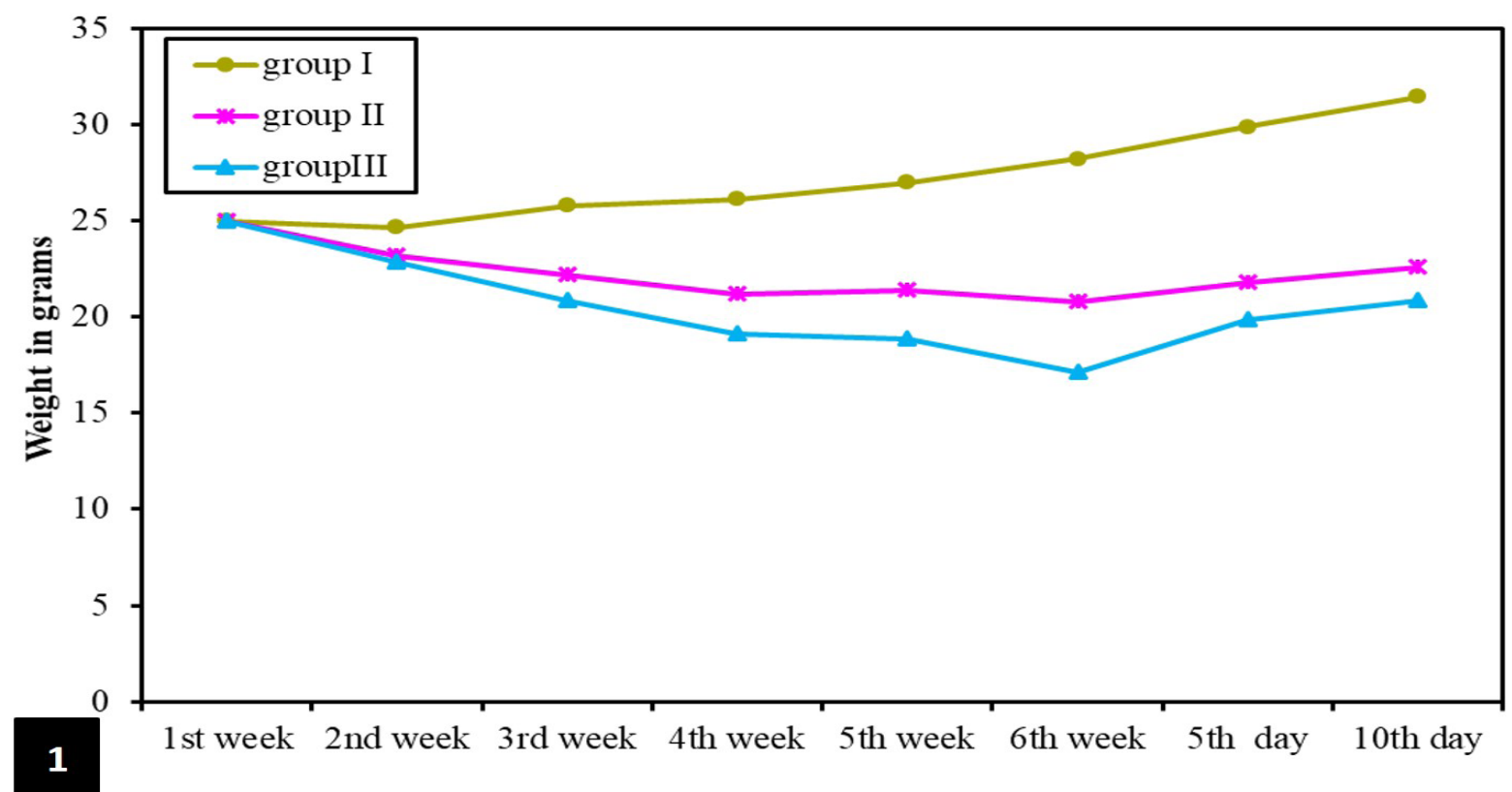

Fig. 1: The body weight curve of mice in the three different groups within the first six weeks and the following 10 days. Data are expressed as mean $\pm \mathrm{SD}$. 

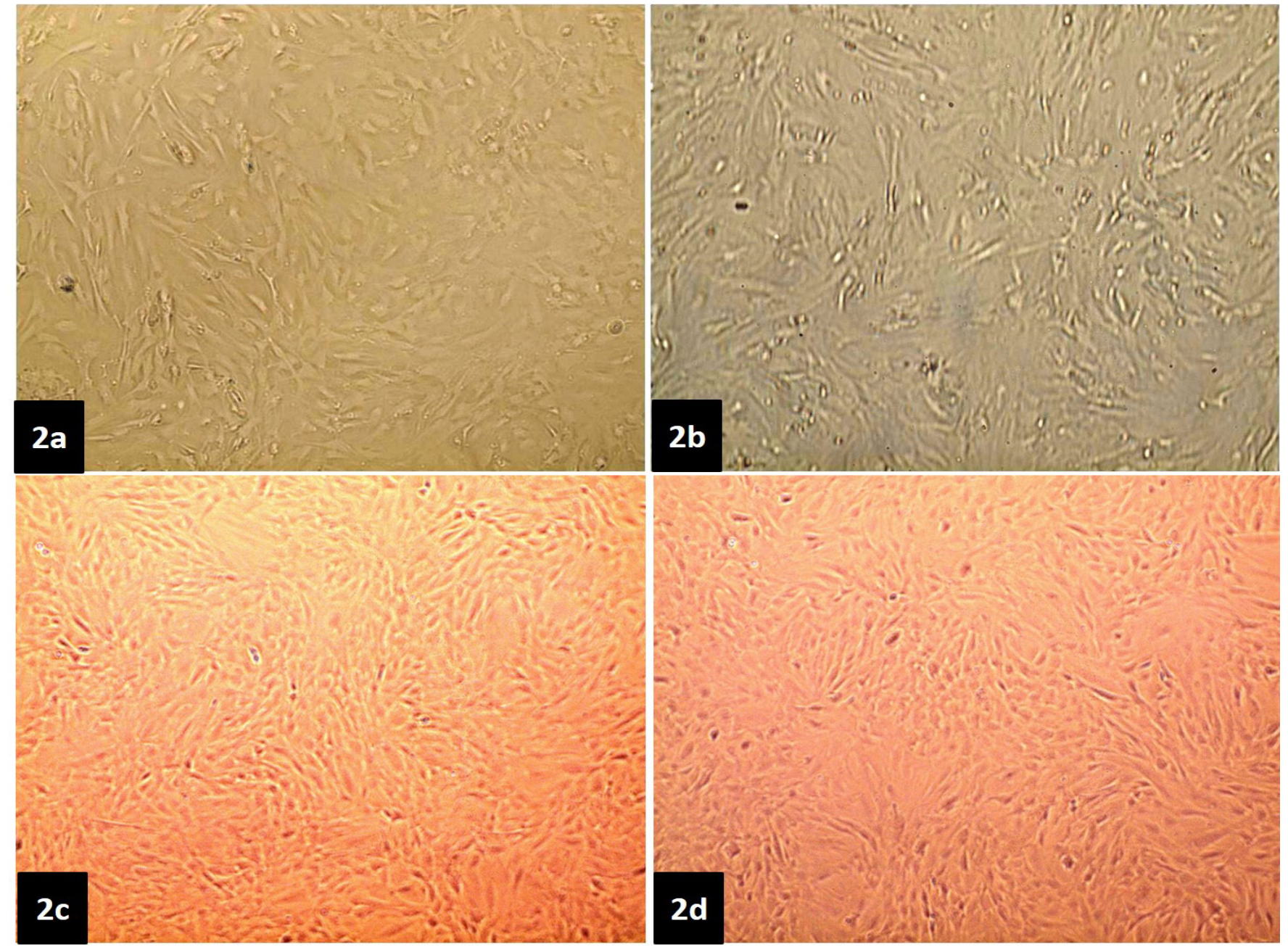

Fig. 2: Photomicrographs of cultured adipose tissue-derived mesenchymal stem

cells showing confluent spindle shaped cells at: (a) passage 0; primary culture, (b) passage 1, (c) passage 2, (d) passage 3. Phase contrast inverted microscopy, Mic. Mag. x 100.
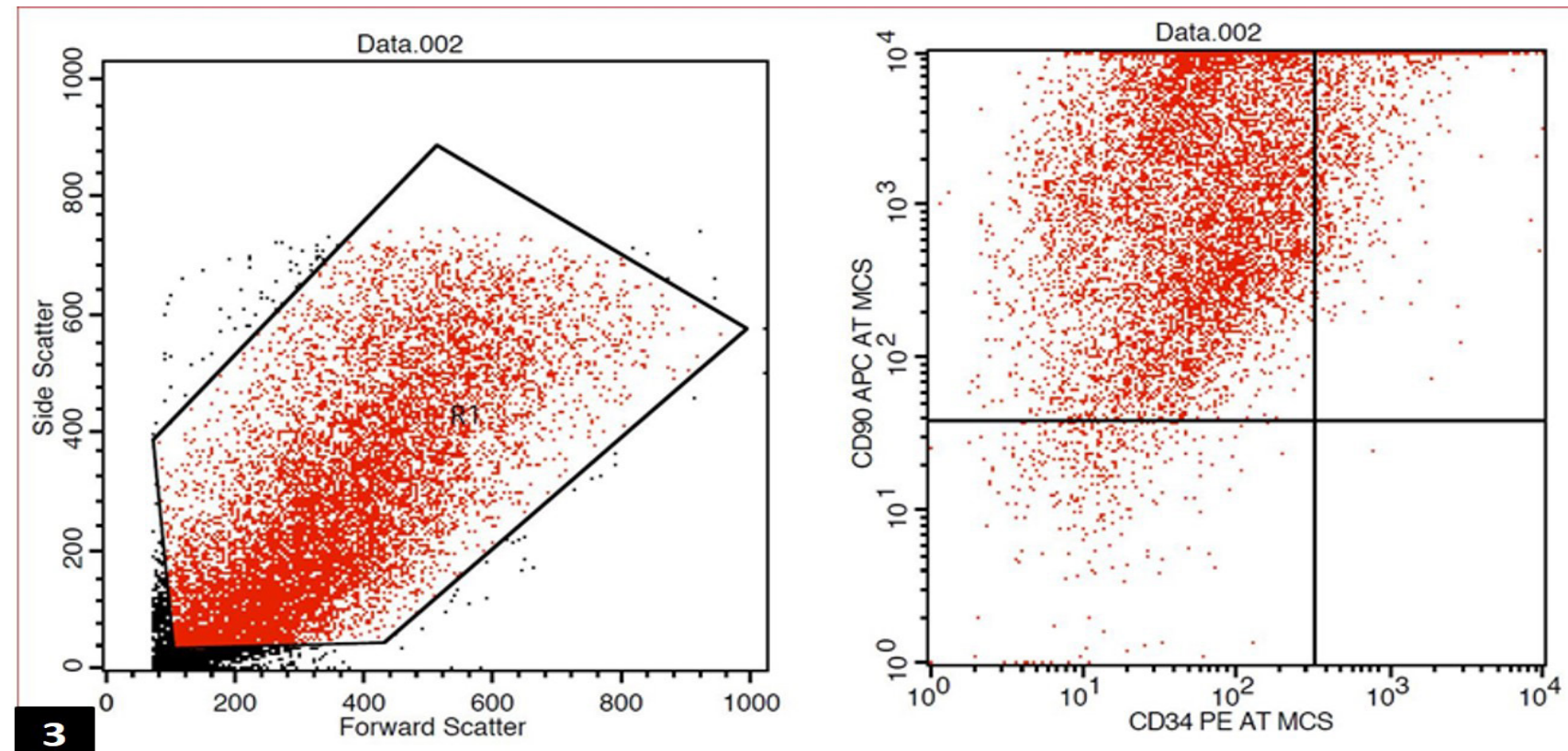

Fig. 3: A representative flow cytometric analysis of AD-MSCs surface markers at passage 3, anti CD90 cells (AD-MSCs) representing $85.1 \%$ (upper left quadrant) while cells positive for anti CD34 only represent $0.01 \%$ of population (lower right quadrant). 


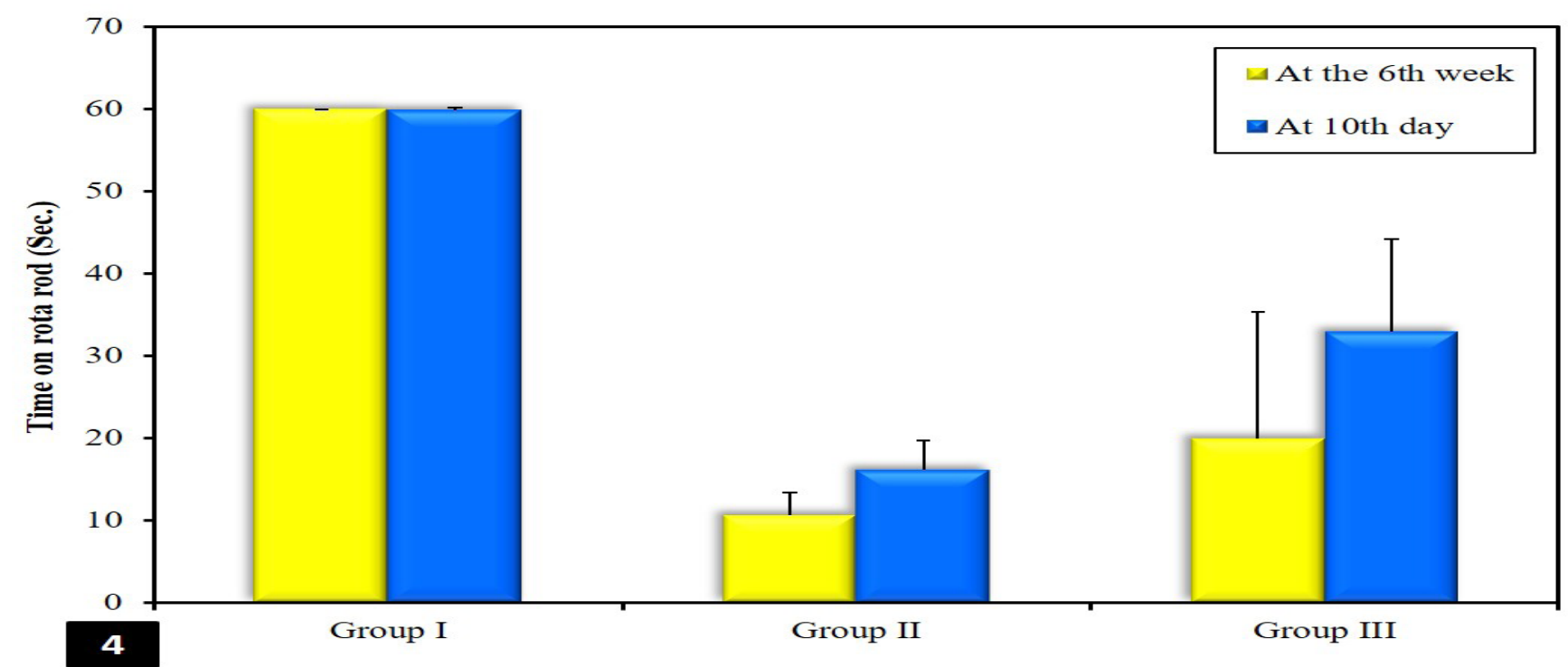

Fig. 4: Bar chart representing the time (in sec.) spent up on Rotarod test for the three different groups at the end of sixth week and ten days later on.
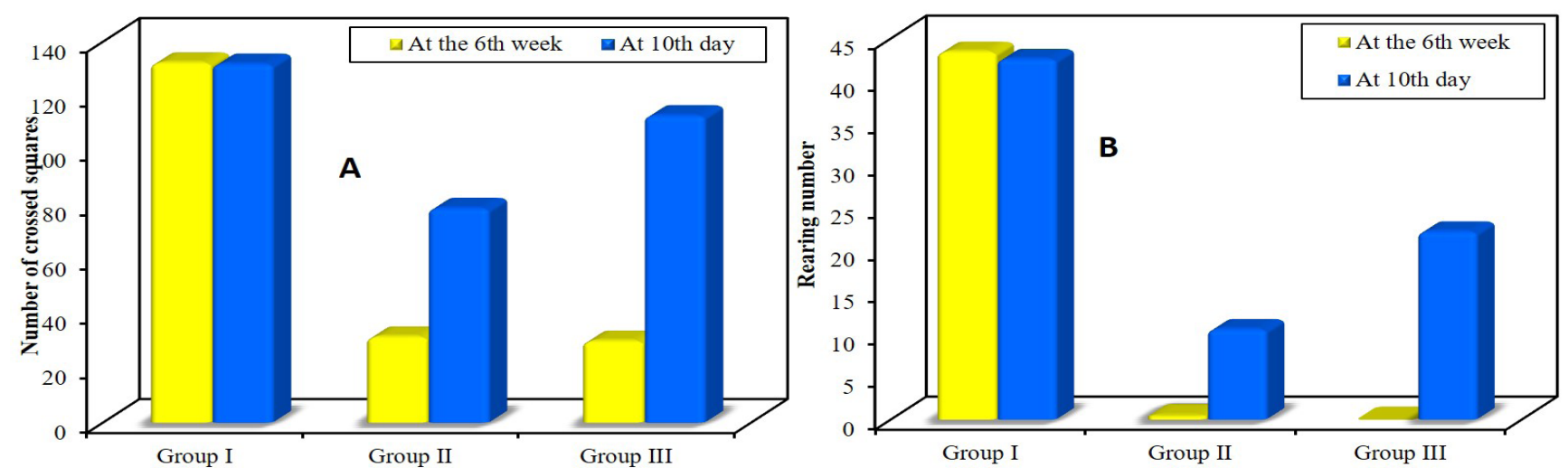

\section{5}

Fig. 5: Two Bar charts representing Open field test, (A)the number of the crossed squares, (B) the number of rearing, in the three different groups at the end of sixth week and ten days later on.

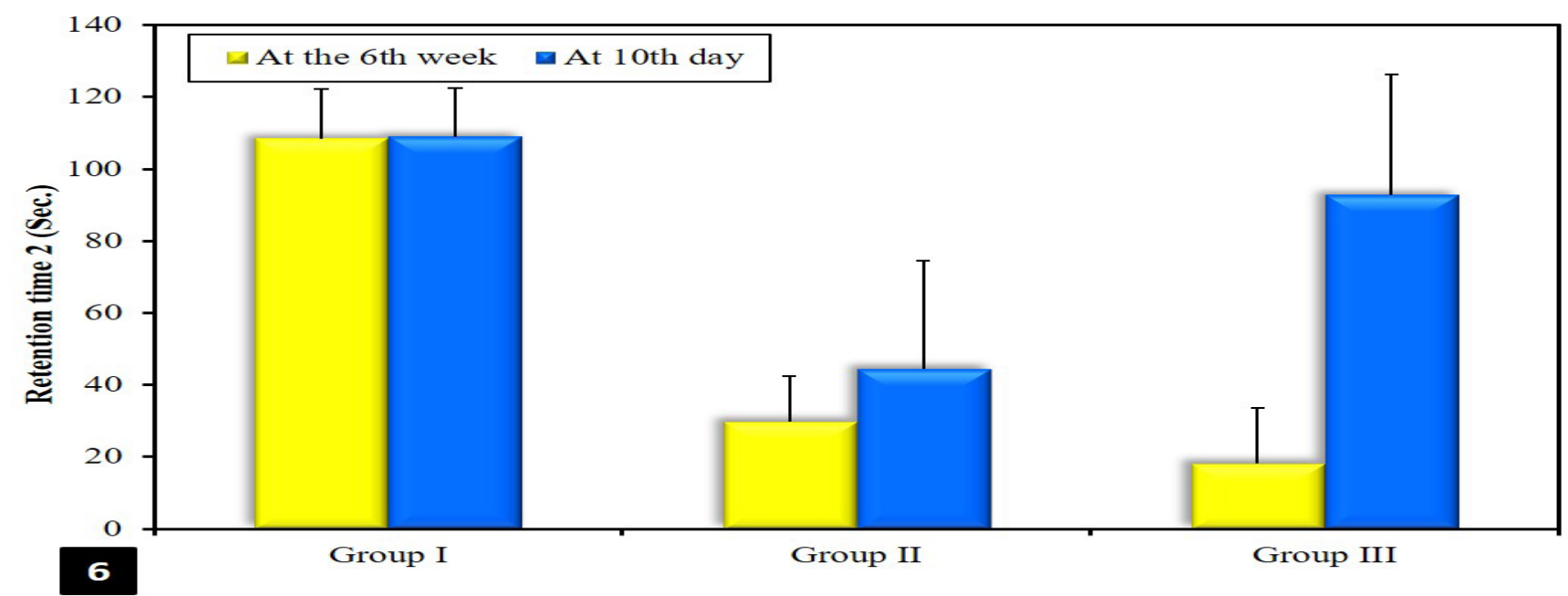

Fig. 6: Bar chart for Passive avoidance test, representing the retention latency time (in sec.) of mice in different experimental groups in the passive avoidance chamber by the end of sixth week and day 10 later on. 


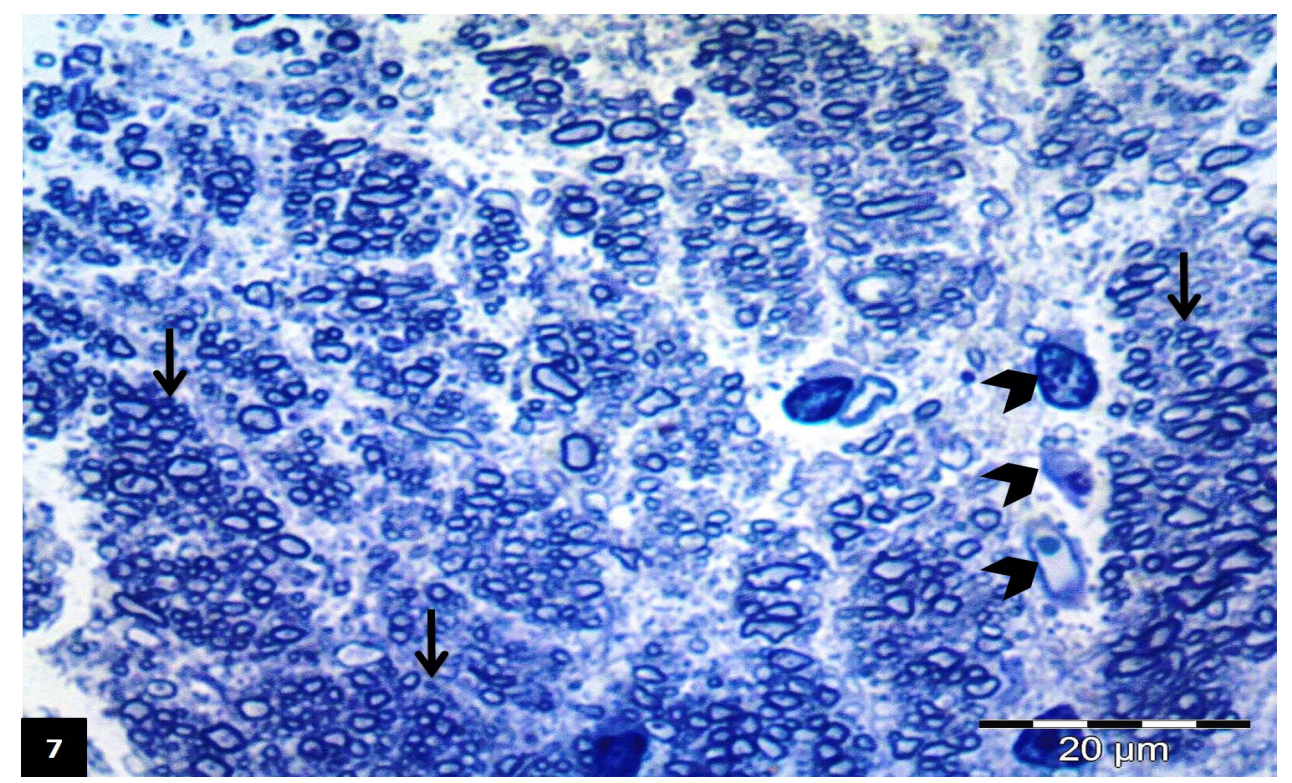

Fig. 7: A photomicrograph of a semithin section of the corpus callosum of control group (group I) showing myelinated nerve fibers arranged in groups (arrow). Few glial cells are seen in rows (arrow head) between the nerve fasciculi. Toluidine blue stain, Mic.Mag. x 1000.
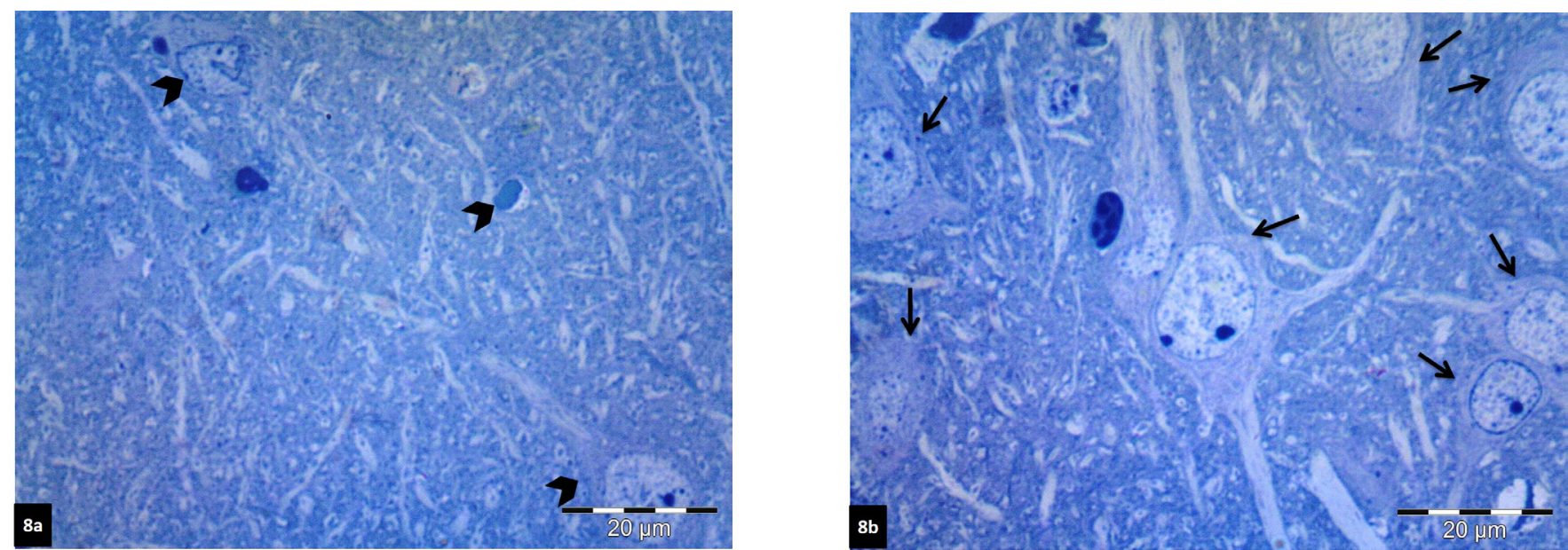

Fig. 8: Photomicrographs of semithin sections of the corpus callosum of demyelinated group (group II) showing: (a) extensively demyelinated corpus callosum with different types of glial cells (arrow head), (b) multiple large astrocytes (arrow) with their processes among demyelinated nerve fibers. Toluidine blue stain, Mic. Mag. x1000.

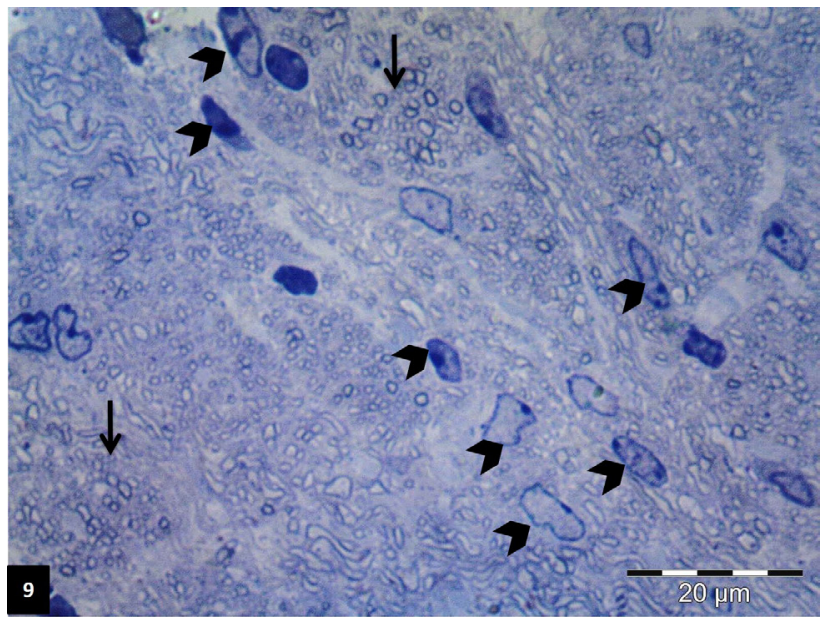

Fig. 9: A photomicrograph of a semithin section of the corpus callosum of transplanted group (group III) showing groups of myelinated nerve fibers (arrow). Numerous glial cells are also observed (arrow head). Toluidine blue stain, Mic. Mag. x1000. 

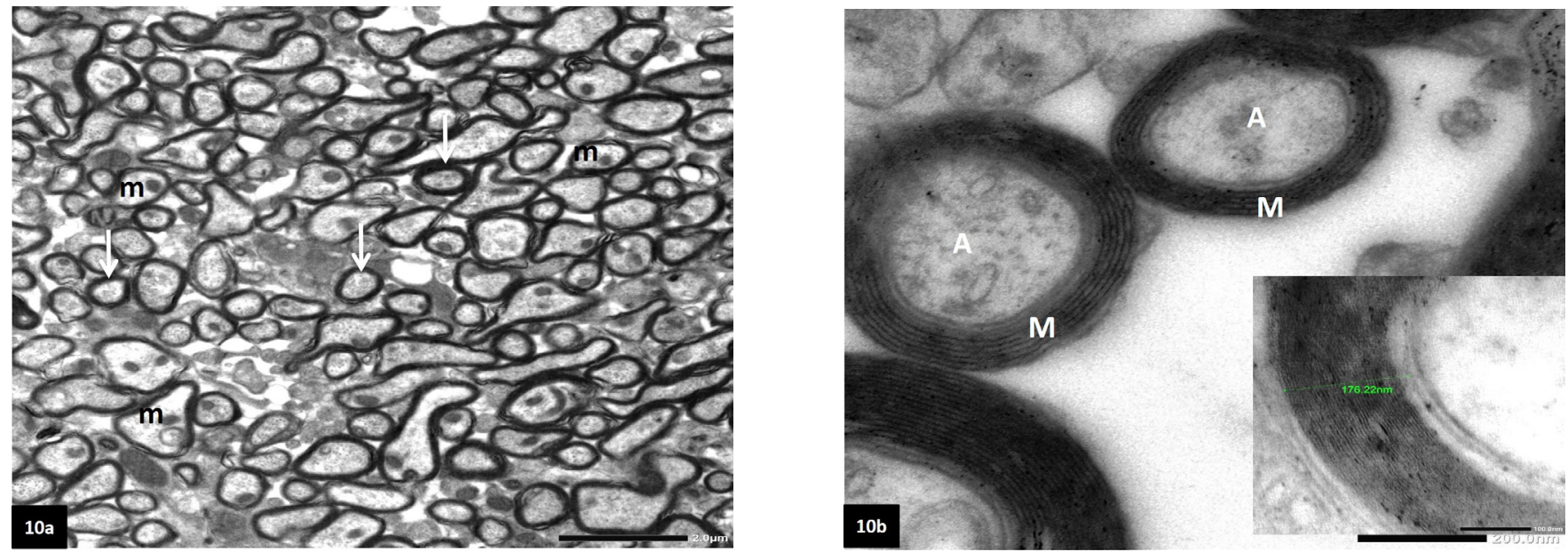

Fig. 10: Electron micrographs of the control corpus callosum showing: (a) myelinated nerve fibers (arrow), (b) each fiber consists of an axon (A) covered by regular and parallel lamellae of the myelin sheath (M), an inset showing a measurement of the thickness of the myelin sheath. Uranyl acetate / lead citrate stain, Mic. Mag. a x 3000, b x 30000, inset x 80000. (m=mitochondria)
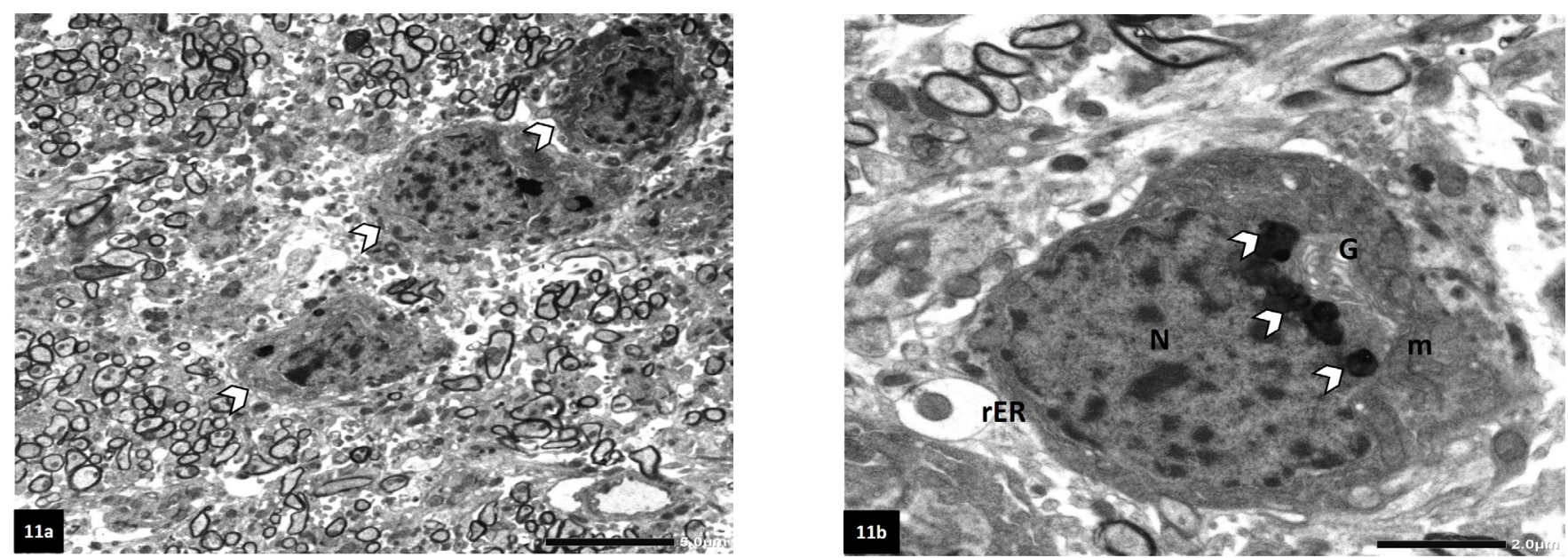

Fig. 11: Electron micrographs of the corpus callosum showing: (a)three oligodendrocytes (arrow head) arranged in a row in between the myelinated nerve fibers, (b) an oligodendrocyte showing dense cytoplasm and a large dense nucleus $(\mathrm{N})$ with clumped peripheral heterochromatin. The cytoplasm contains Golgi apparatus $(\mathrm{G})$, many mitochondria $(\mathrm{m})$, short cisternae of rough endoplasmic reticulum (rER) and some dense inclusions (arrow head). Uranyl acetate / lead citrate stain, Mic. Mag. a x1200, b x3000.

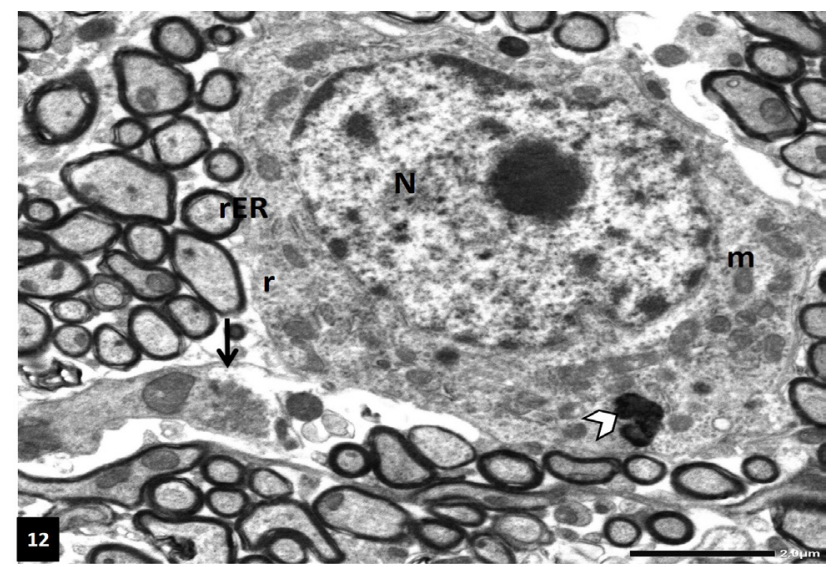

Fig. 12: An electron micrograph of the control corpus callosum showing an astrocyte with irregular shape, pale cytoplasm and pale nucleus $(\mathrm{N})$, with a thin rim of peripheral heterochromatin. The cytoplasm contains multiple mitochondria (m), many ribosomes $(\mathrm{r})$, rough endoplasmic reticulum(rER) and a cytoplasmic inclusion (arrow head). A thin astrocytic process(arrow) is seen adjacent to a group of myelinated nerve fibers. Uranyl acetate lead citrate stain, Mic. Mag. x3000.

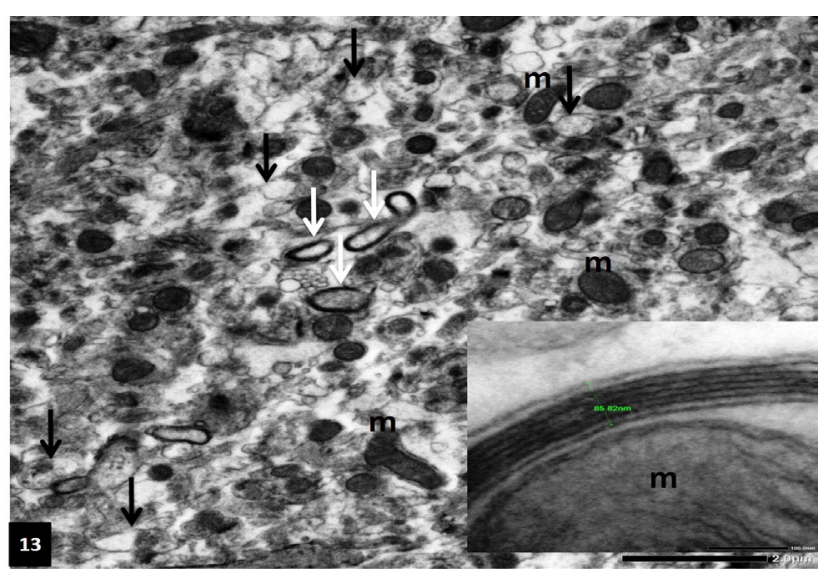

Fig. 13: An electron micrograph of the demyelinated group (group II) showing mostly demyelinated fibers (black arrow) containing enlarged mitochondria $(\mathrm{m})$. Few myelinated nerve fibers (white arrow) are still depicted, an inset showing a measurement of the myelin thickness, note: a part of an enlarged mitochondria (m). Uranyl acetate / lead citrate stain, Mic. Mag. x 3000 , inset x 80000 . 

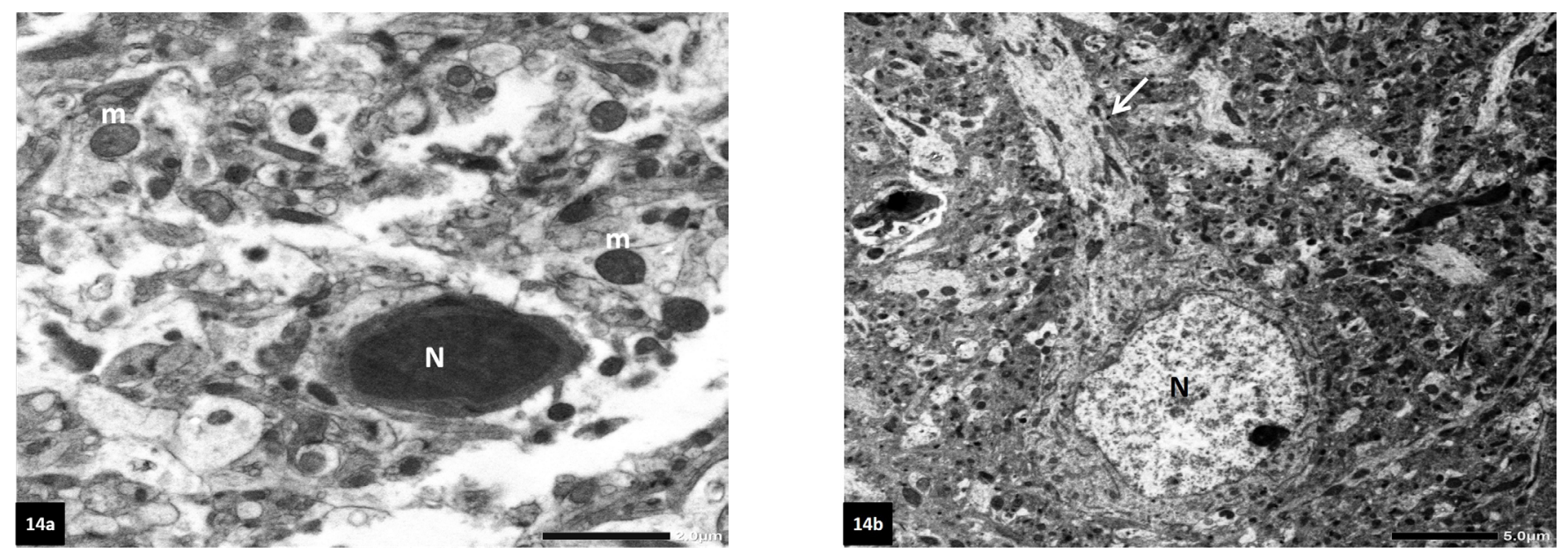

Fig. 14: Electron micrographs of the corpus callosum of the same group. (a) The corpus callosum is seen thoroughly demyelinated with large mitochondria $(\mathrm{m})$ in the axons. One cell shows a small cell body with an elongated heterochromatic nucleus $(\mathrm{N})$, (b) a large astrocyte exhibits an euchromatic nucleus $(\mathrm{N})$ and relatively lucent cytoplasm with long processes (arrow). Uranyl acetate / lead citrate stain, Mic. Mag. a x3000, b x1200.

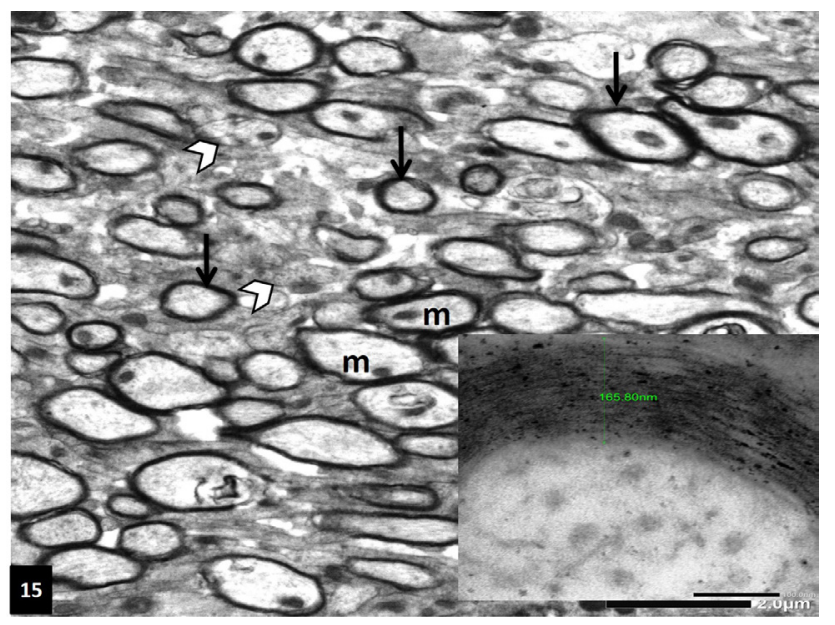

Fig. 15: An electron micrograph of the transplanted group (group III) showing multiple remyelinated nerve fibers (black arrow). Few demyelinated nerve fibers (white arrow head) are also encountered. $\mathrm{m}$; mitochondria inside the axoplasm, an inset showing a measurement of the myelin thickness. Uranyl acetate / lead citrate stain Mic. Mag. x3000, inset x 80000.
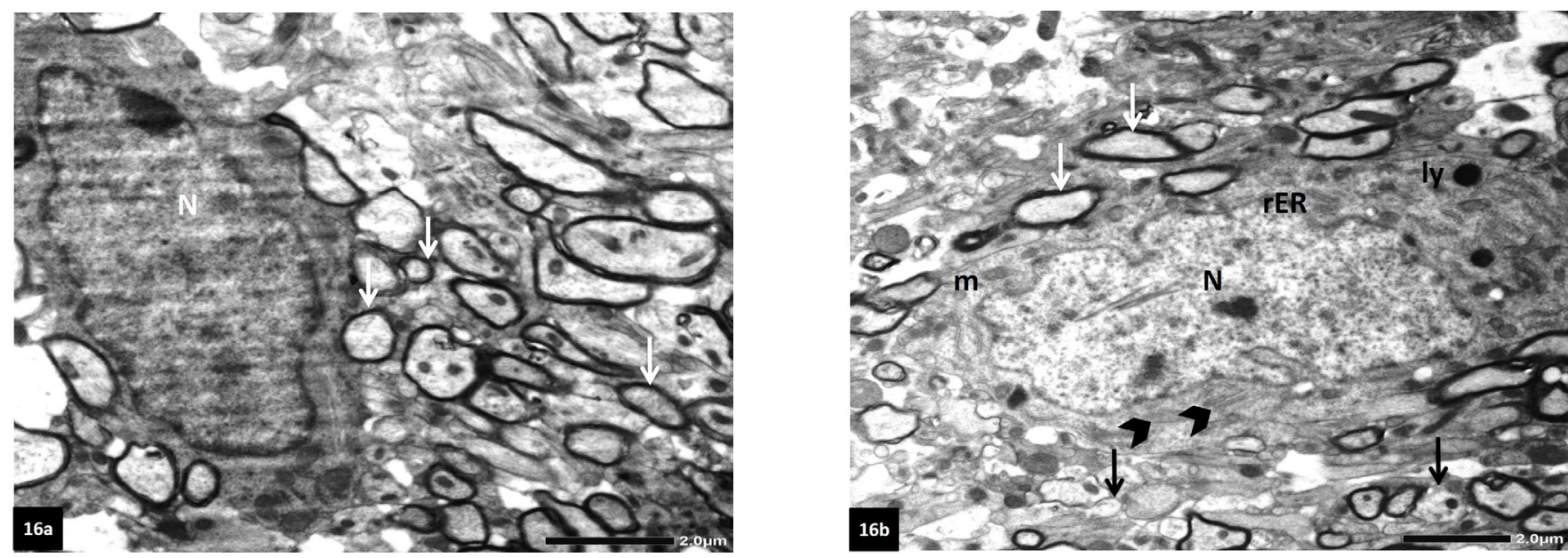

Fig. 16: Electron micrographs of transplanted group showing: (a) an oligodendrocyte with its relatively dense cytoplasm and nucleus (N) surrounding a group of myelinated nerve fibers(arrow), (b) a large astrocyte with an irregular euchromatic nucleus (N), both demyelinated (black arrow) and myelinated (white arrow) nerve fibers are encountered. m; mitochondria, rER; profiles of rough endoplasmic reticulum, ly; lysosome, arrow head; bundles of filaments. Uranyl acetate / lead citrate stain, Mic. Mag. a x2500, b x3000. 


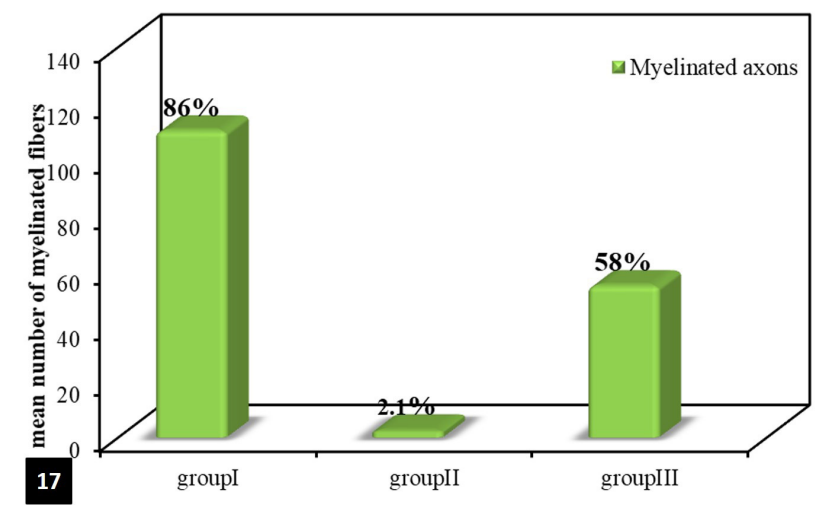

Fig. 17: Bar chart showing the mean number of the myelinated fibers in the three different groups. The percentage of myelinated nerve fibers to the total nerve fibers is shown above each bar.
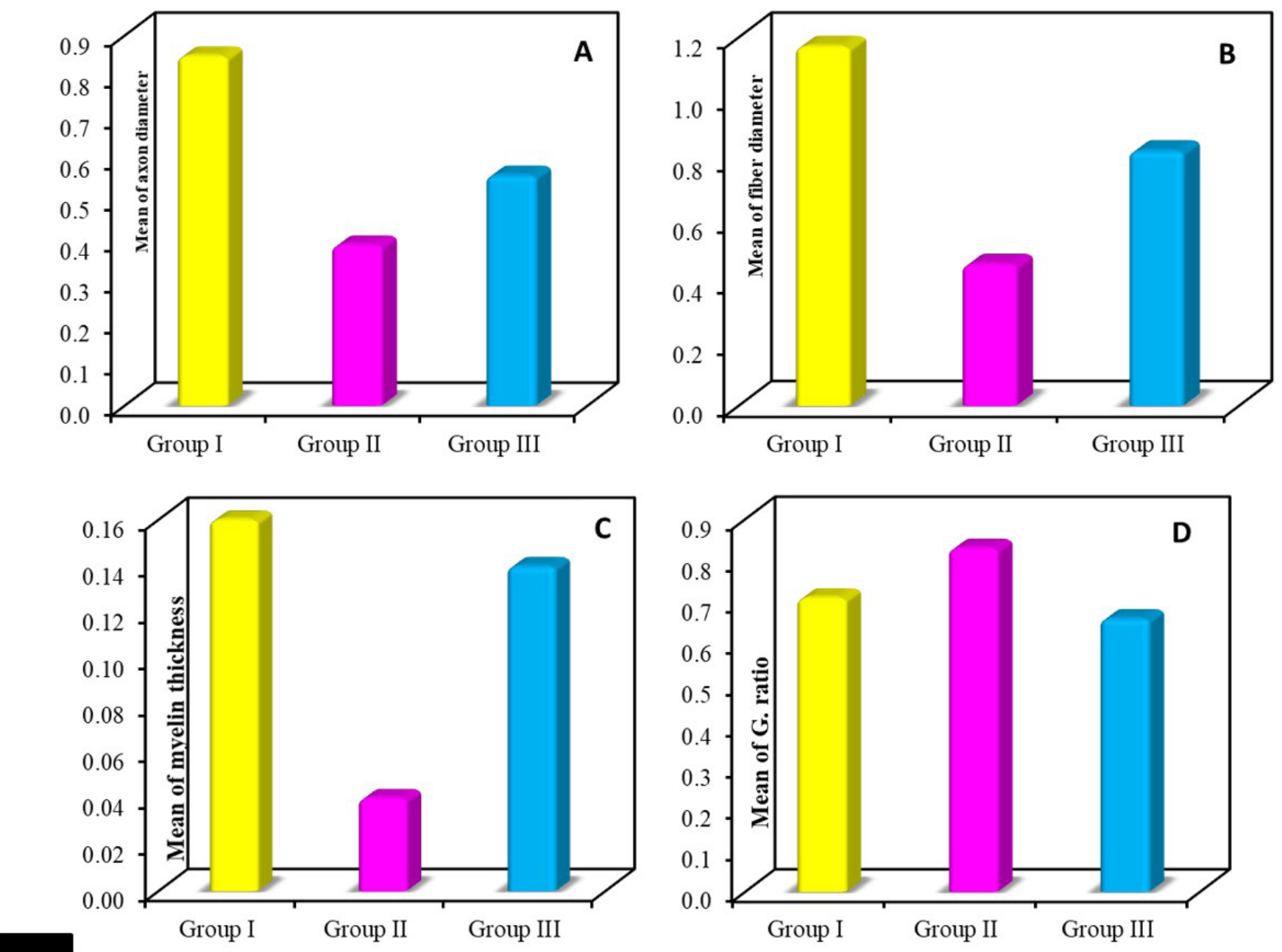

18

Fig. 18: Four Bar charts showing (A) the axon diameter, (B)fiber diameter, (C)the myelin thickness and (D) G-ratio, in the different groups. 


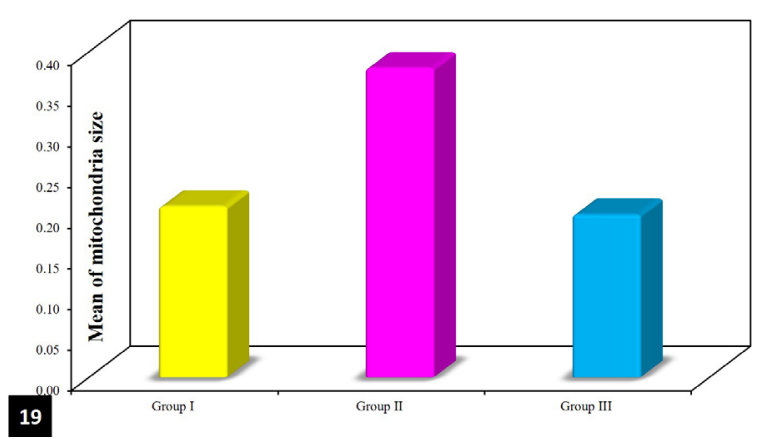

Fig. 19: Bar chart showing the size of the mitochondria in the three experimental groups.

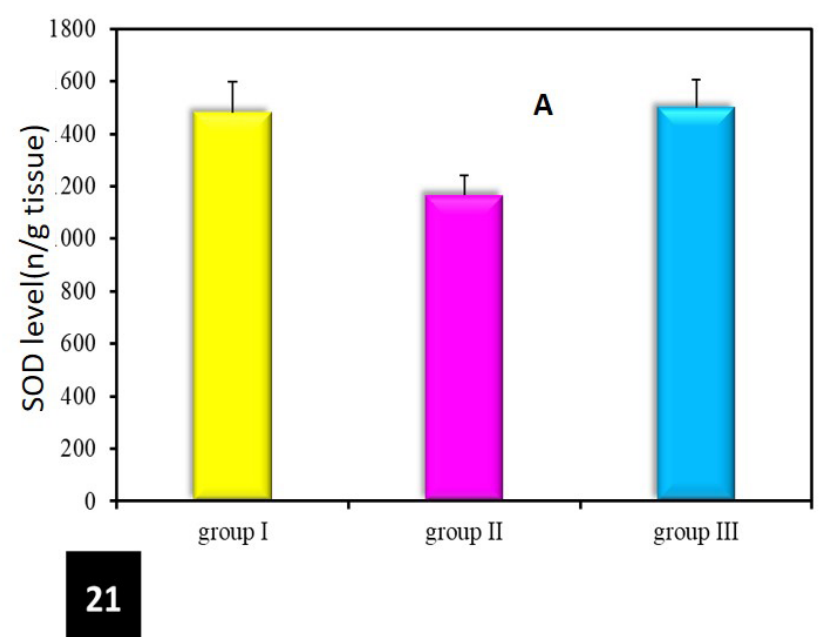

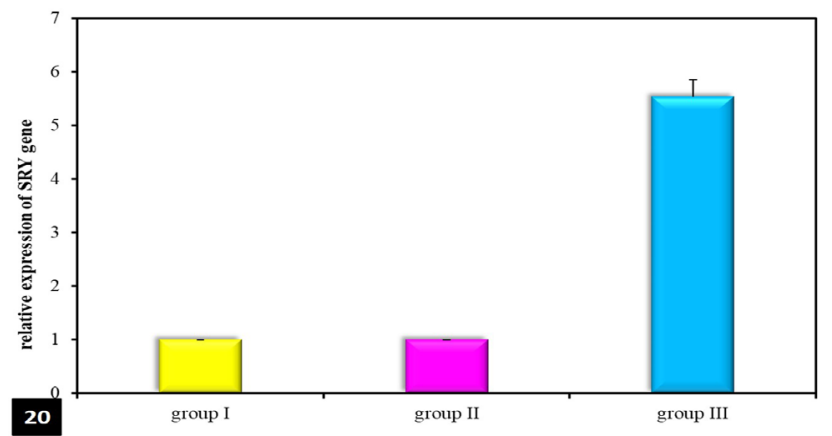

Fig. 20: Bar chart showing SRY mRNA relative expression of gene in the experimental groups.

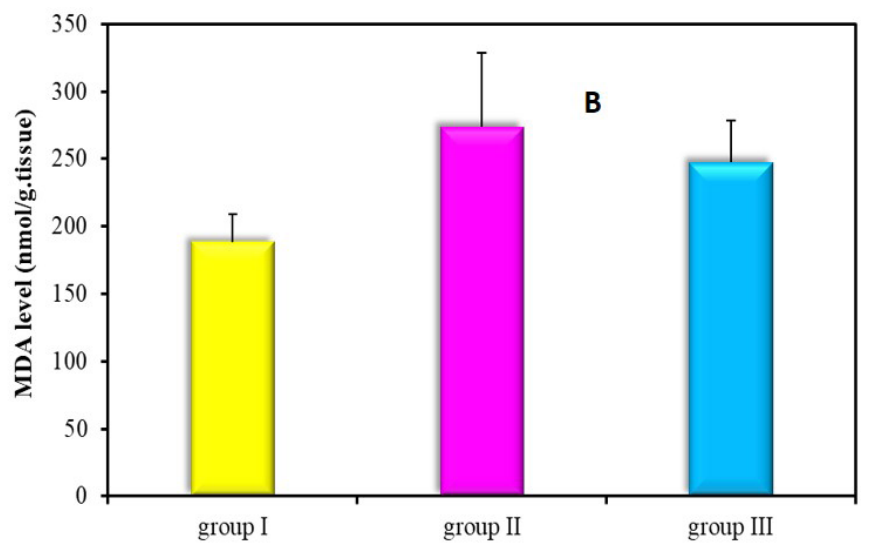

Fig. 21: Two Bar charts showing: (A) SOD activity level (U/g tissue) and (B) MDA level (nmol/g tissue) within the corpus callosum in the different experimental groups.

\section{DISCUSSION}

Multiple sclerosis is a chronic inflammatory demyelinating disease that impacts the patients with disabilities. Conventional drug therapies for MS are insufficient to stop the degeneration of the nerve tissue. In demyelinating diseases, remyelination can be accomplished either by activation of the body own repair mechanism or by transplant of a cell source that promotes the myelination process $^{[24]}$. The stem cells emerge as a potential therapeutic tool in treating the demyelinating disorders, but its source and availability become a key factor for their clinical applications ${ }^{[25]}$.

Mesenchymal stem cells; the most widely used cells, can be harvested from many sources ${ }^{[6]}$. The most common types used in researches are either BM-MSCs or ADMSCs. So far, the phenotype of the AD-MSCs was similar to that of $\mathrm{BM}-\mathrm{MSCs}^{[26]}$. In this regard, this study was conducted on MSCs obtained from adipose tissue because AD-MSCs have several advantages.

In contrast to BM-MSCs, AD-MSCs are easily isolated in higher amounts with less discomfort to the donor. Additionally, AD-MSCs are known to undergo senescence later than BM-MSCs and have a higher proliferative capacity $^{[27]}$. Moreover, AD-MSCs inhibit the proliferation and cytokine secretion of $\mathrm{T}$ cells in response to mitogens ${ }^{[26]}$.
Furthermore, AD-MSCs produce immune modulators and some growth factors such as vascular endothelial growth factor and insulin -like growth factor more than BM$\mathrm{MSCs}^{[28]}$

The present work was conducted on C57BL/6 mice as a model of MS because the genetic background factors affect the susceptibility to demyelination ${ }^{[29]}$. Also, the corpus callosum was selected for histological studies of the central demyelinating diseases because it is so far the largest nerve tract in the CNS which is early affected during the pathogenesis of $\mathrm{MS}^{[30]}$.

Cuprizone (CZ); oxalic acid bis (cyclohexylidene) hydrazone, is a selective copper chelating agent that has been used to induce demyelination of the white matter and consequently to investigate demyelinating diseases such as MS. Indeed, the intracellular level of copper has to be strictly maintained otherwise, neurodegeneration becomes inevitable. It is well established that the oligodendrocytes are in specific, affected by $\mathrm{CZ}$ toxicity owed to their high level of metabolism ${ }^{[31]}$.

In the current study, the weight of mice was decreased following cuprizone-containing diet for 6 weeks. According to Steelman et al, ${ }^{[32]}$ this weight loss could be explained by a reduction in the food intake due to the systemic toxic effect of cuprizone. 
Light and electron microscopic examination of the corpus callosum sections of mice after 6 weeks of cuprizone intake in demyelination group revealed extensive demyelination which was confirmed by morphometric and statistical analyses. This finding was previously reported by Bolcskei et $a l,{ }^{[33]}$ Acs et al, ${ }^{[34]}$ and Pasquini et al ${ }^{[35]}$ works and owed to the toxic effect of $\mathrm{CZ}$ on oligodendrocytes via disturbance in the intracellular level of copper which was accomplished by release of proapoptotic cytokines such as tumor necrosis factor - alpha (TNF- alpha) and interferongamma (INF- gamma) from the recruited microglial and astrocyte cells, eventually, leading to oligodendrocyte apoptosis and myelin disintegration.

In this study, multiple astrocytes were observed by the light microscopy in demyelination group. According to Skripuletz et $a l^{[36]}$ the astrocytes, which have a fundamental role in demyelination and remyelination processes, increase in number following $\mathrm{CZ}$ intoxication, subsequently, they activate and recruit the microglia which are essential in removal of myelin debris; a prerequisite step for proper remyelination.

Meanwhile, the decrease in the size of the axon diameter, fiber diameter, myelin thickness and subsequent increase in the G-ratio, for the demyelination group compared to the control group were in accordance with the work done by Bitsch et al, ${ }^{[37]}$ and could be a result of atrophy and disintegration of the myelinated axons during the acute phase of demyelination.

Additionally, the current morphometric analysis highlighted a significant increase in the size of the mitochondria in the demyelination group compared to the other groups. Meanwhile, Acs et al, ${ }^{[34]}$ considered this finding as a constant change associated with $\mathrm{CZ}$ intake. In accordance with our result, Faizi et al, ${ }^{[38]}$ attributed the so called-megamitochondria formation to the toxic properties of cuprizone on mitochondria due to an increase in the level of reactive oxygen species (ROS), thus, mitochondrial fusion or inhibition of fission occurred in an attempt to decrease the oxidant level.

Moreover, cuprizone intake for 6 weeks affected various brain regions concerned with cognitive and motor performance as a sequence of demyelination ${ }^{[38]}$. This was reflected in the results of different neurological and behavior tests that were performed during the experimental period.

In the current study, the motor deficit was demonstrated by decreased time on the Rotarod test in cuprizone treated mice. This finding was coincidence with many researchers who revealed poor motor co-ordination with administration of $0.2 \%$ cuprizone ${ }^{[39]}$. However, Xiu et a ${ }^{[40]}$ announced that although the time spent upon the Rotarod test decreased in $\mathrm{CZ}$ exposed mice, the result was insignificant compared to the control group. This contradicted results could be attributed to difference in the extent of demyelination among different studies even with the same dose of $\mathrm{CZ}$ and the same duration ${ }^{[41]}$.
According to the Passive avoidance test, the impaired spatial working memory in cuprizone exposed mice observed in the present study corresponded to the published data by Adilijiang et $a l,{ }^{[42]}$ However, Zhang et $a l,{ }^{[43]}$ reported that there is no effect in spatial working memory with cuprizone exposure. This preserved memory may attribute to the short duration of cuprizone exposure during his study which was just seven days only.

Moreover, low exploratory behavior and social withdrawal in the Open field test observed in the current work with cuprizone intake, coincides with the work done by Xu et al in $2009^{[44]}$. This social withdrawal was explained by reduced size of the corpus callosum associated with $\mathrm{CZ}$ intake. Surprisingly, another work done by $\mathrm{Xu}$ et al, ${ }^{[45]}$ later on in 2011 stated that there was an increase in the exploratory behavior with exposure to cuprizone owing to the lower anxiety level of the experimental animals.

Oxidative stress could harm any organ particularly the CNS due to its high oxygen consumption, high level of its polyunsaturated fat and unfortunately, low antioxidant level ${ }^{[46]}$. Consequently, with cuprizone administration, there was an increase in MDA level in the demyelination group accompanied by decrease in the level of SOD; which is the cornerstone in protection against ROS, leading to a decrease in the antioxidant power of the brain. In accordance with our results, ACS et al, ${ }^{[34]}$ found that cuprizone administration in the demyelination group induced low level of SOD activity. Remyelination is defined as the entire restoration of the myelin sheaths that were previously lost with subsequent reestablishing their structural and functional integrity ${ }^{[47]}$.

In the current work, transplantation of the male ADMSCs into the tail vein of the female mice (group III) after the demyelination induced by $\mathrm{CZ}$ intake, resulted in improvement of both histological structure, as shown by the light and electron microscopies, and also physiological performance. These results were further confirmed by morphometric and statistical analyses.

Structurally, this improvement was manifested by the appearance of large number of the remyelinating nerve fibers of the corpus callosum, increased fiber diameter, the myelin thickness and consequently decrease in the G-ratio. Also, the size of the mitochondria decreased to be nearly as the control group.

Functionally, the increase in time on the Rotarod test for the transplanted group in comparison to the demyelination group denoted an improvement of the motor impairment with treatment by AD-MSCs. Also, there was enhancement of the exploratory behavior within the open field which was demonstrated by increasing the distance traveled and the number of rearing. Additionally, the cognitive behavior and long-term memory got better following stem cell transplantation.

Furthermore, AD-MSCs transplantation in group III normalized the activity level of SOD. This effect was 
explained by Lanza et $a l^{[48]}$ as an anti-oxidant effect of AD-MSCs.

Although, there was a hot debate about the role of intravenous injection of stem cells in remyelinating the demyelinated corpus callosum owing to the existence of an intact blood brain barrier (BBB), ${ }^{[49]}$ recent studies have clarified that cuprizone affects endothelial cells of the brain capillaries leading to disruption and downregulation of BBB maintenance factors with increased its permeability which occurred at the peak of demyelinating diseases accompanying $\mathrm{CZ}$ intoxication ${ }^{[50]}$.

Such migration and homing of the male AD-MSCs into the affected female corpus callosum were confirmed in our study by detection of SRY-gene Y chromosome specific sequence by RT-q PCR in the brain specimens of the female black mice.

Indeed, homing of the AD-MSCs begins by binding of very late antigen-4 (VLA-4) integrin to its receptor vascular cell adhesion membrane (VCAM-1) on brain endothelium. (VLA-4) is expressed on AD-MSCs, whereas it is not expressed in BM-MSC. That's why AD-MSCs were superior to BM-MSCs in treatment of demyelinating diseases $^{[51]}$.

The neuro-regenerative power of mesenchymal stem cells referes to the migration, homing, differentiation potential, paracrine secretion, immunomodulatory and anti-inflammatory properties as well as through direct cellcell contact ${ }^{[52]}$. In turn, paracrine effect of mesenchymal stem cells leads to recruitment of progenitor cells and further differentiation to oligodendrocytes, because the already differentiated cells in the demyelinated region are unable to remyelinate the pathologically demyelinated axons. So far, such recovery of myelination was partially attributed to activation of the endogenous progenitor cell repair by $\mathrm{MSCs}^{[53]}$

In contrast, Nessler et al, ${ }^{[54]}$ reported that MSCs did not exert any effect in the central demyelinating diseases in the cuprizone model due to the presence of an intact $\mathrm{BBB}$ and consequently cannot contribute to the process of remyelination. The controversial results of their study compared with the other researchers might be attributed to either the shorter duration of time allowed for cuprizone to induce its toxic effect on endothelial cells of the brain (4-5 weeks) or to the duration given to MSCs to regenerate in the mouse brains as the mice were sacrificed after 3.5 to 7 days after injection.

Thus, the current work reinforced the use of AD-MSCs in the treatment of demyelinating diseases such as MS with the resulted improvement of neurological structure and function.

\section{ABBREVIATIONS}

AD-MSCs: adipose tissue-derived mesenchymal stem cells, BBB: blood brain barrier, BM-MSCs: bone marrow mesenchymal stem cells, CCM: complete cultured medium, CNS: central nervous system, CZ: cuprizone, DEPC: Diethyl-pyro-carbonate, DMEM: Dulbecco's modified Eagle's medium, FACS: fluorescent activated cell sorting, FBS: fetal bovine serum, GAPDH: glyceraldehyde-3phosphate dehydrogenase, MDA: Malondialdehyde, MS: Multiple sclerosis, MSCs: Mesenchymal stem cells, mm: micrometer, P 3: passage3, PBS: phosphate buffered- saline, ROS: reactive oxygen species, RT-qPCR: Real time-quantitative polymerase chain reaction, SOD: Superoxide dismutase, SRY: sexdetermining region Y, SVF: stromal vascular fraction, TEM: transmission electron microscopy, TNF: tumor necrosis factor, VCAM-1: vascular cell adhesion membrane, VLA-4: very late antigen-4, IFN: interferon.

\section{CONFLICTS ON INTEREST}

There are no conflicts of interest.

\section{REFERENCES}

1. El-Akabawy G, Rashed LA. Beneficial effects of bone marrow-derived mesenchymal stem cell transplantation in a non-immune model of demyelination. Ann Anat 2015;198:11-20.

2. Orton SM, Herrera BM, Yee IM, Valdar $\mathrm{W}$, Ramagopalan SV, Sadovnick AD, et al. Sex ratio of multiple sclerosis in Canada: a longitudinal study. Lancet Neurol 2006;5(11):932-6.

3. Miller AE, Wolinsky JS, Kappos L, Comi G, Freedman MS, Olsson TP, et al. Oral teriflunomide for patients with a first clinical episode suggestive of multiple sclerosis (TOPIC): a randomised, double-blind, placebo-controlled, phase 3 trial. Lancet Neurol 2014;13(10):977-86.

4. Bowles AC, Scruggs BA, Bunnell BA. Mesenchymal stem cell-based therapy in a mouse model of experimental autoimmune encephalomyelitis (EAE). Methods Mol Biol 2014;1213:303-19.

5. Koltuniuk A, Rosinczuk J. Adherence to disease-modifying therapies in patients with multiple sclerosis. Patient Prefer Adherence 2018;12:1557-66.

6. Jeon YJ, Kim J, Cho JH, Chung HM, Chae JI. Comparative Analysis of Human Mesenchymal Stem Cells Derived From Bone Marrow, Placenta, and Adipose Tissue as Sources of Cell Therapy. J Cell Biochem 2016;117(5):1112-25.

7. Zappia E, Casazza S, Pedemonte E, Benvenuto F, Bonanni I, Gerdoni E, et al. Mesenchymal stem cells ameliorate experimental autoimmune encephalomyelitis inducing T-cell anergy. Blood 2005;106(5):1755-61. 
8. Luna AC, Madeira ME, Conceicao TO, Moreira JA, Laiso RA, Maria DA. Characterization of adipose-derived stem cells of anatomical region from mice. BMC Res Notes 2014;7:552.

9. Abakumova TO, Kuz'kina AA, Zharova ME, Pozdeeva DA, Gubskii IL, Shepeleva, II, et al. Cuprizone model as a tool for preclinical studies of the efficacy of multiple sclerosis diagnosis and therapy. Bull Exp Biol Med 2015;159(1):111-5.

10. Hedayatpour A, Ragerdi I, Pasbakhsh P, Kafami L, Atlasi N, Pirhajati Mahabadi V, et al. Promotion of remyelination by adipose mesenchymal stem cell transplantation in a cuprizone model of multiple sclerosis. Cell J 2013;15(2):142-51.

11. Tsekouras A, Mantas D, Tsilimigras DI, Moris D, Kontos M, Zografos GC. Comparison of the Viability and Yield of Adipose-Derived Stem Cells (ASCs) from Different Donor Areas. In Vivo 2017;31(6):1229-34.

12. Hashemi SM, Hassan ZM, Pourfathollah AA, Soudi S, Shafiee A, Soleimani M. Comparative immunomodulatory properties of adipose-derived mesenchymal stem cells conditioned media from BALB/c, C57BL/6, and DBA mouse strains. J Cell Biochem 2013;114(4):955-65.

13. Franco-Pons N, Torrente M, Colomina MT, Vilella E. Behavioral deficits in the cuprizone-induced murine model of demyelination/remyelination. Toxicol Lett 2007;169(3):205-13

14. Fan HB, Chen LX, Qu XB, Ren CL, Wu XX, Dong FX, et al. Transplanted miR-219-overexpressing oligodendrocyte precursor cells promoted remyelination and improved functional recovery in a chronic demyelinated model. Sci Rep 2017;7:41407.

15. Tichá I. Hayat, M. A.:Principles and techniques of electron microscopy. Biological applications. Vol. I. Biologia Plantarum 1975;17(2):129-.

16. Bancroft JD, Gamble M. Theory and practice of histological techniques. 4th ed. Philadelphia: Elsevier Health Sciences; 2008.

17. Kuo J. Electron microscopy: methods and protocols. 3rd ed. New Gersy: Humana press incorporation; 2014.

18. Payne SC, Bartlett CA, Harvey AR, Dunlop SA, Fitzgerald M. Chronic swelling and abnormal myelination during secondary degeneration after partial injury to a central nervous system tract. J Neurotrauma 2011;28(6):1077-88.

19. Chomiak T, Hu B. What is the optimal value of the g-ratio for myelinated fibers in the rat CNS? A theoretical approach. PLoS One 2009;4(11):e7754.
20. Nishikimi M, Appaji N, Yagi K. The occurrence of superoxide anion in the reaction of reduced phenazine methosulfate and molecular oxygen. Biochem Biophys Res Commun 1972;46(2):849-54.

21. Ohkawa H, Ohishi N, Yagi K. Assay for lipid peroxides in animal tissues by thiobarbituric acid reaction. Anal Biochem 1979;95(2):351-8.

22. Latronico T, Brana MT, Gramegna P, Fasano A, Di Bari G, Liuzzi GM. Inhibition of myelin-cleaving poteolytic activities by interferon-beta in rat astrocyte cultures. Comparative analysis between gelatinases and calpain-II. PLoS One 2013;8(2):e49656.

23. Wu N, Yu AB, Zhu HB, Lin XK. Effective silencing of Sry gene with RNA interference in developing mouse embryos resulted in feminization of XY gonad. J Biomed Biotechnol 2012;2012:343891.

24. Bai L, Lennon DP, Eaton V, Maier K, Caplan AI, Miller $\mathrm{SD}$, et al. Human bone marrow-derived mesenchymal stem cells induce Th2-polarized immune response and promote endogenous repair in animal models of multiple sclerosis. Glia 2009;57(11):1192-203.

25. Constantin G, Marconi S, Rossi B, Angiari S, Calderan L, Anghileri E, et al. Adipose-derived mesenchymal stem cells ameliorate chronic experimental autoimmune encephalomyelitis. Stem Cells 2009;27(10):2624-35.

26. Yañez R, Lamana ML, García-Castro J, Colmenero I, Ramírez M, Bueren JA. Adipose tissue-derived mesenchymal stem cells have in vivo immunosuppressive properties applicable for the control of the graft-versus-host disease. Stem Cells 2006; 24(11):2582-91.

27. Mohamed-Ahmed S, Fristad I, Lie SA, Suliman $\mathrm{S}$, Mustafa $\mathrm{K}$, Vindenes $\mathrm{H}$, et al. Adiposederived and bone marrow mesenchymal stem cells: a donor-matched comparison. Stem Cell Res Ther 2018;9(1):168.

28. Hsiao ST, Asgari A, Lokmic Z, Sinclair R, Dusting GJ, Lim SY, et al. Comparative analysis of paracrine factor expression in human adult mesenchymal stem cells derived from bone marrow, adipose, and dermal tissue. Stem Cells Dev 2012;21(12):2189-203.

29. Yu Q, Hui R, Park J, Huang Y, Kusnecov AW, Dreyfus $\mathrm{CF}$, et al. Strain differences in cuprizone induced demyelination. Cell Biosci 2017;7:59.

30. Ozturk A, Smith SA, Gordon-Lipkin EM, Harrison DM, Shiee N, Pham DL, et al. MRI of the corpus callosum in multiple sclerosis: association with disability. Mult Scler 2010;16(2):166-77.

31. Benetti F, Ventura M, Salmini B, Ceola S, Carbonera $\mathrm{D}$, Mammi S, et al. Cuprizone neurotoxicity, copper deficiency and neurodegeneration. Neurotoxicology 2010;31(5):509-17. 
32. Steelman AJ, Thompson JP, Li J. Demyelination and remyelination in anatomically distinct regions of the corpus callosum following cuprizone intoxication. Neurosci Res 2012;72(1):32-42.

33. Bolcskei K, Kriszta G, Saghy E, Payrits M, Sipos $\mathrm{E}$, Vranesics A, et al. Behavioural alterations and morphological changes are attenuated by the lack of TRPA1 receptors in the cuprizone-induced demyelination model in mice. $J$ Neuroimmunol 2018;320:1-10.

34. Acs P, Komoly S. Selective ultrastructural vulnerability in the cuprizone-induced experimental demyelination. Ideggyogy Sz 2012;65(7-8):266-70.

35. Pasquini LA, Calatayud CA, Bertone Una AL, Millet V, Pasquini JM, Soto EF. The neurotoxic effect of cuprizone on oligodendrocytes depends on the presence of pro-inflammatory cytokines secreted by microglia. Neurochem Res 2007;32(2):279-92.

36. Skripuletz T, Hackstette D, Bauer K, Gudi V, Pul R, Voss E, et al. Astrocytes regulate myelin clearance through recruitment of microglia during cuprizoneinduced demyelination. Brain 2013;136(Pt 1):147-67.

37. Bitsch A, Schuchardt J, Bunkowski S, Kuhlmann T, Bruck W. Acute axonal injury in multiple sclerosis. Correlation with demyelination and inflammation. Brain 2000;123 (6):1174-83.

38. Faizi M, Salimi A, Seydi E, Naserzadeh P, Kouhnavard M, Rahimi A, et al. Toxicity of cuprizone a $\mathrm{Cu} 2+$ chelating agent on isolated mouse brain mitochondria: a justification for demyelination and subsequent behavioral dysfunction. Toxicol Mech Methods 2016;26(4):276-83.

39. $\mathrm{Xu} \mathrm{H}$, Yang $\mathrm{HJ}$, McConomy $\mathrm{B}$, Browning $\mathrm{R}$, Li $\mathrm{XM}$. Behavioral and neurobiological changes in C57BL/6 mouse exposed to cuprizone: effects of antipsychotics. Front Behav Neurosci 2010;4:8.

40. Xiu Y, Cheng GH, Peng C, Wang Y, Li YD, Chao $\mathrm{FL}$, et al. Ultrastructural abnormalities and loss of myelinated fibers in the corpus callosum of demyelinated mice induced by cuprizone. J Neurosci Res 2017;95(8):1677-89.

41. Hibbits $\mathrm{N}$, Pannu $\mathrm{R}, \mathrm{Wu} \mathrm{TJ}$, Armstrong RC. Cuprizone demyelination of the corpus callosum in mice correlates with altered social interaction and impaired bilateral sensorimotor coordination. ASN Neuro 2009;1(3).

42. Adilijiang A, Guan T, He J, Hartle K, Wang W, Li X. The Protective Effects of Areca catechu Extract on Cognition and Social Interaction Deficits in a Cuprizone-Induced Demyelination Model. Evid Based Complement Alternat Med 2015;2015:426092.
43. Zhang $\mathrm{H}$, Zhang $\mathrm{Y}$, Xu H, Wang L, Zhao J, Wang $\mathrm{J}$, et al. Locomotor activity and anxiety status, but not spatial working memory, are affected in mice after brief exposure to cuprizone. Neurosci Bull 2013;29(5):633-41.

44. Xu H, Yang HJ, Zhang Y, Clough R, Browning R, Li XM. Behavioral and neurobiological changes in C57BL/6 mice exposed to cuprizone. Behav Neurosci 2009;123(2):418-29.

45. Xu H, Li XM. White matter abnormalities and animal models examining a putative role of altered white matter in schizophrenia. Schizophr Res Treatment 2011;2011:826976.

46. Wei LF, Zhang HM, Wang SS, Jing JJ, Zheng ZC, Gao JX, et al. Changes of MDA and SOD in Brain Tissue after Secondary Brain Injury with Seawater Immersion in Rats. Turk Neurosurg 2016;26(3):384-288.

47. Irvine KA, Blakemore WF. Remyelination protects axons from demyelination-associated axon degeneration. Brain 2008;131(Pt 6):1464-77.

48. Lanza C, Morando S, Voci A, Canesi L, Principato MC, Serpero LD, et al. Neuroprotective mesenchymal stem cells are endowed with a potent antioxidant effect in vivo. J Neurochem 2009;110(5):1674-84.

49. McMahon EJ, Suzuki K, Matsushima GK. Peripheral macrophage recruitment in cuprizone-induced CNS demyelination despite an intact blood-brain barrier. J Neuroimmunol 2002;130(1-2):32-45.

50. Berghoff SA, Duking T, Spieth L, Winchenbach J, Stumpf SK, Gerndt N, et al. Blood-brain barrier hyperpermeability precedes demyelination in the cuprizone model. Acta Neuropathol Commun 2017;5(1):94.

51. Constantin G, Majeed M, Giagulli C, Piccio L, Kim JY, Butcher EC, et al. Chemokines trigger immediate beta2 integrin affinity and mobility changes: differential regulation and roles in lymphocyte arrest under flow. Immunity 2000;13(6):759-69.

52. Kassis I, Grigoriadis N, Gowda-Kurkalli B, Mizrachi-Kol R, Ben-Hur T, Slavin S, et al. Neuroprotection and immunomodulation with mesenchymal stem cells in chronic experimental autoimmune encephalomyelitis. Arch Neurol 2008;65(6):753-61.

53. Fancy SP, Zhao C, Franklin RJ. Increased expression of Nkx2.2 and Olig2 identifies reactive oligodendrocyte progenitor cells responding to demyelination in the adult CNS. Mol Cell Neurosci 2004;27(3):247-54.

54. Nessler J, Benardais K, Gudi V, Hoffmann A, Salinas Tejedor L, Janssen S, et al. Effects of murine and human bone marrow-derived mesenchymal stem cells on cuprizone induced demyelination. PLoS One 2013;8(7):e69795. 


$$
\text { الملخص العربى }
$$

\section{التأثير العلاجي المحثمل لزرع الخلايا الجذعية الوسطيه المستمدة من النسيج الاهنى على نموذج كوبريزون لمرض التصلب المتعدد فى الفئران

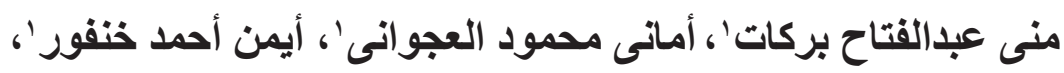

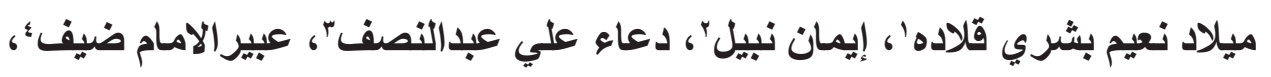

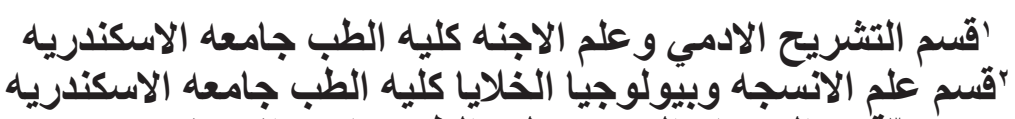

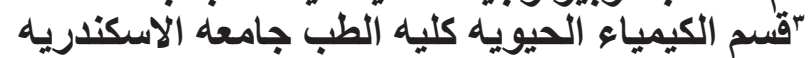

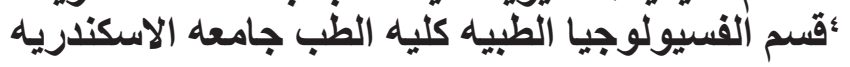

المقدمه: التصلب المتعدد هو مرض مناعي ذاتي ينتج عنه تنكس فى الغثاء العازل للاعصاب. العقاقير التقليدية المستخدمه حاليا في العلاج لا تستطيع إيقاف تلف النسيج العصبي. لذلك تعتبر الخلايا الجذعيه فى الوقت الحالى اداة علاجية محتملة في كثير من امر اض التنكس العصبي وذللك لخصائصها المناعية المتميزهو طبيعتها المغذية وقدرتها علي التمايز إلى أنو اع متعددة الانساب مما جعلها الاختيار الامثل فى العلاج. الهدف من البحث: أجريت هذه الدر اسة لاستكشاف الدور العلاجي للخلايا الجذعية الوسطية المشتقة من النسيج الدهنى في إعادة تكوين غثاء الميالين العازل للاعصاب فى نموذج مرض التصلب المتعدد المحدث بالكوبريزون. مواد وطرق البحث: تم عزل الخلايا الجذعية الوسطية من ذكور الفئران و تمييز ها باستخدام جهاز عد الخلايا. قسمت جب أنثى من الفئران إلى ثلاث مجمو عات. تم تغذيه فئر ان المجمو عه الاولي ( المجموعة الضابطة) بحميه خاليه من الكوبريزون طو ال مده البحث. المجموعه الثانيه والثالثه تم تغذيتهم بحميه مضاف اليها الكوبريزون لمده سته اسابيع تليها حقن وريدي لـ . .0 ميكرولتر من الوسط المتكامل للمجموعه الثانيه بينما تم حقن المجموعه الثالثه بمليون من الخلايا الجذعية الوسطية المستمده من النسيج الدهنى علقت في . .0 ميكرولتر من الوسط المتكامل. الاختبارات العصبية اجريت قبل الحقن وتم اعادتها خلال اليوم التاسع و العاشر من الحقن. وبحلول نهاية الفترة التجريبية فى اليوم العاثر، تمت التضحية بالفئران عن طريق قطع الر أس وإزالة الدماغ للحصول على الجسم الثفني لاستخدامه في الفحص النسيجي و الكيمائي وتم إجر اء در اسة مورفومنرية لتقييم إعادة تكوين غشاء الميالين كما تم الكثف عن هجره الخلايا الجذعية الوسطية , و التي تم الحصول عليها من الذكور , الي دماغ إناث الفئر ان بالمجمو عة الثالثة بو اسطة التعبير الجيني SRY. اخير ا تم تحليل النتائج احصائيا. النتائج : تتاول الكوبريزون لمده ستة اسابيع متو اصله نتج عنه إز الة واسعة للميالين من الالياف العصبية فى الجسم الثفني مماثلا لما يحدث فى مرض التصلب المتعدد, مما نتج عنه العجز العصبي وزياده في الاكسده. الحقن الوريدي 
بالخلايا الجذعيه الوسطية المشتقة من النسيج الدهنى فى المجموعة الثالثة نتج عنه اعادة تكوين الميالين حول الالياف العصبية ومن ثم تحسين الوظائف الحركية والإدر اكية وخفض مستوى الأكسدة.

الاستتتاج: الخلايا الجذعيه الوسطيه المشتقة من النسيج الدهنى تمثل علاج محتمل للامر اض التنكسية العصبيه ومنها مرض التصلب المتعدد. 